\title{
Çocukların Yer Aldığı Reklamların Çocuklara ve Yetişkinlere Verilen Mesajlar, Roller ve Cinsiyete Yönelik Ayrımcılık Unsurları Açısından İncelenmesi
}

\author{
Fulya Ezmeci \\ Esra Tuğba Çoban Söylemez \\ Esra Akgül \\ Berrin Akman
}

araştırma görevlisi, hacettepe üniversitesi, eğitim bilimleri enstitüsü fulya.ezmeci@hacettepe.edu.tr, esratuba@hacettepe.edu.tr, esra.kose@hacettepe.edu.tr

profesör, hacettepe üniversitesi eğitim fakültesi bakman@hacettepe.edu.tr

\begin{abstract}
The Analysis of Advertisements Give Place to Children in Terms of Messages Given to Children and Adults, Roles and SexBased Discrimination Components

Nowadays, media is used for many different purposes beyond entertainment, such as information, marketing, sales-perception management. The advertisements are short term but very effective tools of media and children frequently appear in advertisements as message carrier or targets of message. This research aimed to examine the roles of children and adults who related to children; the messages given to children and adults by means of children and sex-based discrimination components that are taken part in advertisements. Within this context, TV programs that have the highest ratings in the prime time period - 20.00-22.59 - were determined. In 21-27 December 2015 dates, the advertisements that take place between these programs and hold child component were determined, analyzed and interpreted with qualitative research design. In the research, it has been determined that children

Bu makaleye referans vermek için: Ezmeci, F., Çoban Söylemez, E. T., Akgül, E. ve Akman B. (2017). Çocukların Yer Aldığı Reklamların Çocuklara ve Yetişkinlere Verilen Mesajlar, Roller ve Cinsiyete Yönelik Ayrımcılık Unsurları Açısından İncelenmesi. Galatasaray Üniversitesi Illeti-ş-im Dergisi, 26, 247-279. DOI: 10.1678/gsuilet.324859.
\end{abstract}


are mostly shown as family members, their families are directed to buy with an emphasis on parenting feelings and children are encouraged to negative behaviors in the advertisements. It has also been observed that there are frequent sexual discrimination components in advertisements.

keywords: media, child, advertisement, message, role

\section{Résumé}

\section{L'analyse des publicités où sont présents les enfants, en termes de messages donnés aux enfants et aux adultes, des rôles et des données à propos de la discrimination sexuelle}

De nos jours, les médias sont davantage utilisés pour l'information, le marketing, la gestion de perception-vente et à d'autres fins que celles du divertissement. Les publicités sont des outils médiatiques de courte durée mais elles sont efficaces et les enfants sont souvent concernés par les publicités soit en tant que transmetteur de message soit en tant que cible. Cette recherche vise à examiner les rôles des enfants et ceux des adultes par rapport aux enfants; les messages donnés aux enfants et aux adultes via les enfants; et les données à propos de la discrimination sexuelle dans les publicités. Dans cet objectif, les émissions de télévision ayant le plus grand taux d'audience dans les heures de grande écoute - de 20 h00 à 22 h59 -, entre le 21 décembre 2015 et le 27 décembre 2015 furent précisées. Les publicités qui se sont diffusées au cours de cette période et dans ces créneaux d'horaire et contenant un certain composant à propos des enfants furent choisies, analysées et interprétées dans une approche qualitative. Il a été observé que les enfants sont le plus souvent présentés comme un membre de la famille; leurs familles sont orientées vers l'acte d'achat par l'accentuation des sentiments parentaux; et les comportements négatifs des enfants sont encouragés dans les publicités. Par ailleurs il a été également observé que la discrimination sexuelle est présente dans les publicités.

mots-clés : média, enfant, publicité, message, rôle 


\section{Öz}

Günümüzde medya eğlendirmenin ötesinde bilgilendirme, pazarlama, satışalgı yönetimi gibi birçok farklı amaçla kullanılmaktadır. Reklamlar medyanın kısa zamanlı fakat etkili kullanılabilen araçlarıdır ve çocuklar da mesaj iletici ya da hedef kitle olarak reklamların içerisinde sıklıkla yer almaktadırlar. Bu çalışma çocukların yer aldığı reklamlarda çocuklara ve çocuklarla ilişkili yetişkinlere verilen rolleri, çocuklara ve çocuklar aracılığı ile yetişkinlere verilen mesajları ve reklamlarda yer alan cinsiyete yönelik ayrımcılık unsurlarını incelemek amacıyla yapılmıştır. Bu kapsamda en çok televizyon izlenme oranlarına sahip prime time -20.00:22.59 saat diliminde- en yüksek reytingli programlar belirlenmiştir. 21-27 Aralık 2015 tarihleri arasında bu programlar arasında yayınlanan reklam kuşakları içerisinde çocuk öğesini herhangi bir şekilde barındıran reklamlar saptanmış, analiz edilmiş ve nitel araştırma deseninde yorumlanmıştır. Araştırmada, reklamlarda çocukların en çok ailenin bireyi olarak gösterildikleri, ailelerinse ebeveynlik duygularına vurgu yapılarak satın almaya yönlendirildikleri ve çocukların da olumsuz davranışlara özendirildikleri belirlenmiştir. Ayrıca reklamlarda sıklıkla cinsiyete yönelik ayrımcılık unsurlarının bulunduğu da görülmüştür.

anahtar kelimeler: medya, çocuk, reklam, mesaj, rol 


\section{Giriş}

Insanlar gelişen teknoloji ile beraber kolay internet erişimi ve geniş yelpazedeki televizyon programları sayesinde günlerinin hemen hemen her anında medya ve iletişim araçları ile etkileşim halindedirler (Temizyürek ve Acar, 2014). Illetişim araçlarından biri olan televizyon, toplumun çeşitli kesimlerine mesajlar verebilmesi ve bu mesajlar aracılığıyla insanlar üzerinde istenilen düşünceyi oluşturabilme etkisine sahip olması nedeniyle de medya kullanıcıları tarafından etkili bulunmaktadır (Acar ve Öcel, 2013; Temizyürek, 2014).

Türkiye'de ve Avrupa ülkelerinde günde 18 saate yakın açık olan televizyon, Amerika'da 2-5 yaş aralığındaki çocuklar tarafından haftada yaklaşık 27 saate kadar izlenmektedir. Bu sürede çocuklar sadece kendilerine yönelik değil, yetişkinler için hazırlanan programları ve birçok reklamı da izlemek durumunda kalmaktadırlar (Centerwall, 1992; Cesur ve Paker, 2007). Deveci ve diğerleri (2007) yaptıkları çalışmada, ilkokul düzeyindeki çocukların \% 99'unun gün içerisinde televizyon izlediğini, ortalama televizyon izleme sürelerinin ise hafta içi 5-6, hafta sonu ise 4-5 saat arası olduğunu belirtmişlerdir. Başka bir çalışmada ise 222 çocuktan \% 35,1'nin (78) kendi odasında televizyonu olduğu saptanmış ve çocukların üçte birine yakınının hafta sonları televizyon bağımlısı oldukları belirtilmiştir (Aksaçlıoğlu ve Yılmaz, 2007).

Babaroğlu'na (2015) göre "Çocuk açısından sosyalleşme, bir öğrenme sürecidir". Çocuk, toplumdaki uygulamaları ve bireylere düşen rolleri bu sosyalleşme sürecinde edinmekte ve sonraki gelişim dönemlerinde edindiği bu bilgilere göre kalıplar oluşturmaktadır. Medyadan aldığı mesajlarla çocuk, sadece tüketim veya alışverişe yönlendirilmez, aynı zamanda yetişkinlerden farklı olarak öğrenme çağında olan çocuklar, televizyonda yer alan programlardan içinde bulundukları toplumun yaşayış biçimi, yetişkin/cinsiyet rolleri, etik kurallar gibi kavramları da öğrenirler (Babaroğlu, 2015). Kaya ve Tuna (2008) tarafından 249 çocuk ile yapılan bir çalışma, televizyon aracılığıyla çocukların popüler kültürden etkilendiklerini ve araştırma kapsamındaki çocukların yarıından fazlasının popüler kültürün bir parçası olmak istediklerini göstermiştir. Çocuklar, toplumla ilgili yayınları izleyerek medyada kendilerine gösterilen bu toplumun bir parçası olmak istemekte ve toplumu bütünüyle televizyonda gördükleri şekilde düşünebilmektedirler (Babaroğlu, 2015).

İçerisinde bulunduğumuz bilgi çağının önemli özelliklerinden birisi de tüketime olan yöneliştir. Artan tüketim nedeniyle genişleyen bir pazar ve bu pazarda da artan rekabet doğal bir sonuç olarak değerlendirilebilir. Bu rekabetçi tüketim ortamında üreticiler ürünlerini insanlara birçok farklı kanaldan sunmakta ve satışlarını artırmak için ürünlerinin özelliklerini tanıtırken, aynı zamanda çeşitli pazarlama stratejileri ile insanların markaya yönelik fikirlerinin oluşmasına, güvenlerinin sağlanmasına ve ürünlerin satımasına yönelik mesajlar da vermektedirler (Baudrillard, 2011; Yazgan, Kethüda ve Çatı 2014). Üreticilerin 
kullandığı en önemli pazarlama araçlarından biri olarak değerlendirilebilecek reklamlar ise İnal ve Baysal'ın (2008) belirttiği gibi tüketicilerin ürünleri değerlendirmesine ve satın alma süreçlerine katkı sağlamaktadır. Reklamlar ürün hakkında izleyicilere bilgi vermenin yanı sıra, izleyicide ürünle ilgili olumlu değerler oluşturarak ürünü satın almak için izleyicileri ikna etmeyi amaçlar. Reklamların yoğun olarak yayınlandığı televizyon ele alındığında, televizyon izleyicilerinin belli bir oranını çocukların oluşturduğu görülmekte ve genç nesiller için televizyon ile kültür kaçınılmaz bir şekilde iç içe geçmektedir (Gigli, 2004). Çocuk ve genç kitle kendilerine ait önemli seviyede bir pazarın oluşması ve bu pazar üzerinden ailelerinin tüketimlerine olan etkileri ile pazarlama bölümünün dikkatini çekmiştir (Gunter ve Furnham 1998). 50'li yıllardan itibaren gelişen ekonomi ile çocuklara yönelik bir pazar oluşturulmaya, 80'ler sonrası çocukların pazardaki markaları tanımalarına önem verilmeye ve 90'lı yıllardan itibaren alışverişlerde çocukların fikirleri önem kazanmaya başlamıştır (Pecora, 2002). 90'lar sonrası araştırmalarda ise bebeklerin altı aylık oldukları dönemlerde ürünlerin logolarını fark etmeye ve logolara tepki vermeye başladıkları, üç yaşına geldiklerinde istedikleri ürünleri betimlemede marka isimlerini kullandıkları, mağazalardaki ürünlerin markalarını tanıdıkları ve 4 yaşlarında yayın akışında çıkan reklamları fark ettikleri sonuçlarına ulaşılmıştır (Burns, 1999; Kaur ve Singh, 2006; Pecora, 2002; Aktaş, Özüpek ve Altunbaş, 2011).

Medyada yer alan reklamlarda çocuklar izleyici kategorisinde yer almakla birlikte, reklamların karakterleri olarak da kullanılmaktadırlar. Modeller (2002) yaptığı araştırmada çocukların haberlerde yetişkinlere geleceğin garantisi, yaşanan zor durumların mağduru ya da zor durumlardan kurtarılan mağdur olarak yer aldığını, ayrıca çocuk kavramının melek kavramı ile özdeşleştirilip, masumiyet ve savunmasızlığa vurgu yapıldığını belirtmiştir. Verilen haberler ile yaratılmak istenilen etki çocukların rolleri ile şekillendirilmektedir. Haberlerde olduğu gibi reklamlarda da çocuklar çeşitli rollerde kullanılmaktadırlar. Çocuğa ya da yetişkine yönelik ürün reklamlarında kimi zaman doğrudan çocuklara mesaj verilmekte, kimi zaman ise çocuk aracılığıyla yetişkinlere mesaj verilmektedir. Elden ve Ulukök'e göre (2006) reklamlar ürünle tüketici arasındaki büyük mesafeleri ortadan kaldırmak ve arada duygusal bir bağ kurulmasını sağlamak amacıyla iletişimsel olarak da bir hedefe sahiptir. Eğer reklamcılar ürünle çocuk arasında bu bağı oluşturabilirlerse, çocukları o ürünün müşterisi olarak kazanabilmekte ve bu bağ çocukların kendilerine bağlı müşteriler olarak kalmalarını sağlamaktadır.

Çocukların birçok ülkede reklam içeriklerinde farklı rollerde yer aldıkları ve birçok marka tarafından sıkça tercih edildikleri görülmektedir. Türkiye'de yayınlanmakta olan çeşitli reklamların geniş yelpazede çocuklara nasıl yer verdiklerine yönelik araştırmalar alanda pek yer almamaktadır. Bu araştırma ile çocukların yer aldığı reklamlar, çocuklara ve çocuklar aracılığı ile yetişkinlere vermek istedikleri mesajlara, çocukların reklamlarda temsil ettikleri rollere ve reklamlarda yer alan cinsiyete dayalı ayrımcılık unsurlarına göre incelenmiştir. 
Alanda bu kapsamda yapılacak ilk çalışmalardan olması sebebiyle alana önemli katkı sağlayacağına inanılmaktadır.

\section{ilgili Araştırmalar}

Alan yazında 'çocuk ve reklam' kapsamında yapılan çalışmalar değerlendirildiğinde bir alt başlık olarak reklamların içeriklerini inceleyen çalışmalar ele alınabilir. Tokgöz (1979) Ankara ili Çankaya ilçesinde ikamet eden 4-6 yaş grubundaki 100 anaokulu öğrencisi ve 7-12 yaş grubundaki 200 ilkokul öğrencisi ile gerçekleştirdiği çalışmasının sonuçlarında; çocukların reklam konusunda pasif değil aktif olduklarını, reklamlardan edinilen bilgilerin çocuklar tarafından çeşitli bilişsel süreçlerden geçirildiğini, yaş değişkeninin çocukların reklamlardaki kavramları kavramasında etkili çok etkili olmadığını, aile ve yakın çevrenin ise çocuk üzerinde etkili olduğunu belirtmiştir. Neeley ve Schumann (2004) ortalama 43-46 aylık 12 okul öncesi dönem çocuğu ile yapmış oldukları çalışmalarında animasyonların kullandığı reklamların okul dönem çocuklar için oldukça dikkat çekici olduğu, fakat ürün ile reklamların ilişkilendirilişinde yüksek etkisinin olmadığı sonucuna ulaşmışlardır. Rose, Merchant ve Bakır (2012) ise çalışmalarının sonuçlarını; çocukların hayal ürünü içeren reklamlara karşı pozitif tutumlarının olduğu, hikâye ve akışta ise gerçekliğe odaklandıkları ve son olarak da reklamlar ve manipüle edilen niyetleri hakkında çocukların farklı fikir ve düşüncelerinin oluştuğu şeklinde üç başlıkta toplamışlardır. Bakır, Palan ve Kolbe, 2013 yılında Meksika, Amerika ve Türkiye'de beş hafta boyunca Çarşamba günleri öğleden sonra 15.00 - 17.30 saatlerinde ve Cumartesi sabahları 8.00 12.00 saatleri arasında kayda alınan reklamlar örneğinde, okul öncesi dönem çocuklarına yönelik hazırlanan reklamların Amerika'da, Türkiye ve Meksika televizyon kanallarında yayınlanan reklamlara göre daha az sosyal içerikli, daha çok doğrudan ürün satımına yönelik olduklarını belirlemişlerdir. Ülkelere göre karşılaştırmaların yapıldığı bir başka çalışma ise Neto ve Furnham tarafından 2005 yılında gerçekleştirilmiş̧ir. Çalışmada iki özel, bir devlet Portekiz kanalında sabah 8.00 - 12.00 arası yayınlanan reklamlar kaydedilmiş, reklamlardaki cinsiyet rolleri ele alınmış ve erkek karakterlere yer verilen reklamlar daha saldırgan, daha aktif, daha sesli olarak değerlendirilirken, kız karakterlerin yer aldığı reklamlar daha hassas, daha sessiz bulunmuştur. Ayrıca erkek karakterlerin yer aldığı reklamlarda şiddet öğesinin vurma, kırma, ölüm-öldürme gibi şekillerde çok daha fazla yer aldığı saptanmıştır. Benzer bir çalışma da Lewin Jones ve Mitra tarafından 2009 yılında yapılmış; hafta içi okuldan önce 7.00-9.00 saatlerinde, okuldan sonra 15.30-17.00 saatlerinde ve hafta sonu 7.30-11.30 saatlerinde iki kanalın reklamları kaydedilmiştir. Neto ve Furnham'ın çalışmasındaki sonuçlara benzer şekilde, erkeklere yönelik reklamlar daha sesli, şiddetli olarak değerlendirilmiştir. Aynı zamanda 4-10 yaş arası 12 çocukla da yapılan reklam izleme ve görüşmelerle çocukların reklamları ve içerikleri erkekçe - kızca şeklinde ayırıp yorumladıkları görülmüştür. Çocukların cinsiyet stereotipi yer alan reklamları değerlendirirken aslında tamamen cinsiyetçi davranmadıkları ve cinsiyet rol modelleri konusunda esnek olduğu sonucuna ulaşan çalışmalar da alanda yer almaktadır (Beentjes, 
Janssen, 2009). Çocuklar aslında cinsiyet stereotipini keskin ve ayrımcı bir bakışla değerlendirmezken, Kalan (2010) yaptığı çalışmasında Kinder markasının reklamlarında kız ve erkek cinsiyet rollerini iki ayrı şekilde ele aldığını göstermiştir. Eisend ve Steinhagen'in (2011) çalışmasında da reklamlarda kadın figürlerin evde, evle ilgili, bağımlı rollerde yer aldığı, erkeklerinse daha özgür bireysel ve hareketli hem ev içi hem ev dışı daha geniş yelpazede roller aldıkları sonucuna ulaşılmıştır. Yücel ve Kara (2007) ile Uluyağcı ve Yılmaz (2007) çalışmalarında Türkiye'deki reklamlarda cinsiyet rollerive çocukların üstlendiği rollerin amaçlarını ele almışlardır. Bu çalışmalarda, çocukların reklamlarda mesaj gönderici konumunda (sunucu, yetişkin bebek, şarkıcı, deney yapan çocuk, dış ses), özne konumunda (çizgi film kahramanı, birleştirici öge), alıcı konumunda (bebek, korunmaya muhtaç çocuk, gücül kullanıcı çocuk) ve engelleyici konumunda yer aldıkları ve sonuçları belirtilen diğer çalışmalarla benzer şekilde kadın cinsiyetinin daha anaç, geleneksel ve pasif olarak yansıtılırken erkek rollerin daha aktif, özgür, bireysel, otorite, karar verici olarak yansıtıldığı söylenmektedir. Çocukların reklamlara tepkileri ve reklamlar sonucu ürünlere yönelim ve tercihleri de çeşitli çalışmalarda incelenmiş; aileleri ile birlikte alışveriş etkinliğine daha sık daha aktif katıım sağlamakta olan çocukların artık sadece ailelerin kararlarını etkilemek için değil, kendi ürün ve alışveriş yönelimlerinin de belirlenmesinin hedeflendiği sonuçlarına ulaşılış̧ır (Cesur ve Paker, 2007; Ateşoğlu ve Türkkahraman, 2009; Johannes, Janssen, 2009; Bakır, Palan, 2010; Aktaş, Özüpek ve Altunbaş; 2011; Gülarslan, 2011). Reklamların çocuklar üzerindeki etkileri de çeşitli çalışmalarda ele alınmış, bu çalışmalarda aile ekonomisinin bir ferdi olduğu söylenen çocukların reklamlardan yaşlarına, kardeş sayılarına, ailelerinin ekonomik düzeylerine, odalarında televizyonları olup olmaması gibi faktörlere göre farklı düzeyde, paralel anlamda etkilendikleri belirlenmiştir (Preston, 1999; Bergler, 1999; Kurt, Altun, 2014; Önder, Dağal, 2015). Nefat ve Dujmovic (2012) tarafından yapılan çalışmada da reklamlar ile tüketici olarak çocukların ve ailelerin tutumları incelenmiştir. Çocukların reklamlarda yer almasına ilişkin hukuksal çerçeve ve düzenlemeler ise Elden ve Ulukök (2006), Yılmaz (2014), Avşar ve Özenirler (2014), Dural ve Dural (2015)'in yaptıkları çeşitli araştırmalarda ele alınmıştır. Kaziaj (2016) tarafından çocukların Arnavut televizyonlarında -haberlerde- temsili üzerine yapılan çalışmada, haberlerde çocukların iki ana rolde, 1. minnet duyan, yalvaran yan roller ve 2 . kurban rolünde yer aldığı saptanmıştır. Oskay'ın (2015) Algida markasının Amaze ürününün reklam serisinde çocuk oyuncuların rollerini incelediği araştırma ise, çocuk ve reklam başlı̆̆ındaki sınırlı çalışmalar içerisinde çocuğun televizyonda temsiline dair yapılmış olan alandaki diğer bir çalışmadır.

\section{Araştırmanın amacı}

$\mathrm{Bu}$ çalışmanın temel amacı, içinde çocukların yer aldığı reklamları; reklamlarda çocuklara ve çocuklarla ilişsili yetişkinlere verilen rolleri, çocuklara ve çocuklar aracılığı ile yetişkinlere verilen mesajları ve reklamlarda yer alan cinsiyete dayalı ayrımcılık unsurlarını incelemektir. 


\section{Araştırma soruları}

- Araştırmada bu amaç doğrultusunda aşağıdaki araştırma sorularına yer verilmiştir:

- Reklamlarda çocukların aldığı roller nelerdir?

- Reklamlarda çocuklar ile birebir ilişkideki yetişkin rolleri nelerdir?

- Reklamlarda çocuklar aracılığı ile yetişkinlere verilmek istenen mesajlar nelerdir?

- Reklamlarda çocuklara verilen mesajlar nelerdir?

- Reklamlarda yer alan cinsiyete dayalı ayrımcılık unsurları nelerdir?

\section{Yöntem}

Bu çalışma temel nitel araştırma deseniyle oluşturulmuştur. Temel nitel araştırmalar; verilerin görüşmeler, gözlemler ya da doküman incelemesi yoluyla toplandığı yaygın nitel araştırma biçimleridir. Bu desende hangi soruların sorulduğu, neyin gözlemlendiği, hangi dokümanların ilişkili kabul edileceği çalışmanın teorik çerçevesine bağlıdır. Veri analizi ise veriyi karakterize ederek tekrarlayan örüntüleri belirlemeyi içerir. Bulgular, bu yenilenen kalıplar ya da türetildikleri veri tarafından desteklenen temalardır (Merriam, 2013). Çalışmadaki veriler nitel araştırmalarda kullanılan veri toplama yöntemlerinden doküman incelemesi yoluyla toplanmıştır. Toplanan verilerin analizinde nitel araştırma analiz yöntemlerinden betimsel analiz kullanılmıştır.

\section{Örnekleme süreci}

Araştırmada amaçı̈ı örnekleme yöntemlerinden ölçüt örnekleme yöntemi kullanılmıştır. Yıldırım ve Şimşek (2013) ölçüt örneklemeyi 'bu yöntemdeki temel anlayış önceden belirlenmiş bir dizi ölçütü karşılayan bütün durumların çalışımasıdır' şeklinde ifade etmektedir. Burada sözü edilen ölçüt veya ölçütler araştırmacı tarafından oluşturulabilir ya da daha önceden hazırlanmış bir ölçüt listesi kullanılabilir. Çalışmanın örneklemini oluşturan reklamlar belirlenirken ölçütler; televizyonun evlerde en çok izlenme saat aralığı (prime time - 20:00-23:00) ve bu aralıkta izlenme düzeyi en yüksek olan programların yayın akışında verilen reklamlar olarak ele alınmıştır. Bu çalışmada 21-27 Aralık 2015 tarihleri arasında Televizyon İzleme Araştırmaları Anonim Şirketi (TIAK) reyting sonuçları kontrol edilerek en çok izlenme oranına sahip alan programlar listelenmiş ve Kırgın Çiçekler (Pazartesi, ATV), Eşkıya Dünyaya Hükümdar Olmaz (Salı, ATV), Diriliş 'Ertuğrul' (Çarşamba, TRT), Kurtlar Vadisi Pusu (Perşembe, KANALD) Karagül (Cuma, FOX TV), O Ses Türkiye '(Cumartesi- Pazar TV 8) olarak saptanmıştır. Daha sonra bu programların yayını esnasında program aralarında verilen reklamlar incelenmiş ve çocukların yer aldığı 32 reklam çalışmaya dâhil edilmiştir. Araştırmaya konu alan reklamların \% 18,5'inde çocuk figürü bulunduğu saptanmıştır. 


\section{Veri toplama süreci}

Örnekleme sürecinde yer verilen programlar araştırmacılar tarafından izlenerek çocukların rol aldığı reklamlar kayıt altına alınmıştır. Bu amaçla doküman incelemesi yapılmıştır. Doküman incelemesi, araştırılması hedeflenen olgu ve olaylar hakkında yazıı materyallerin analizini kapsamaktadır. Yazılı kaynakların yanı sıra; film, video ve fotoğraf gibi görsel malzemeler de nitel araştırmalarda kullanılmaktadır. Nitel araştırmalar tek başına bir veri toplama yöntemi olarak kullanılabileceği gibi, diğer veri toplama yöntemleri ile de desteklenebilmektedir (Yıldırım ve Şimşek, 2013).

Araştırmanın güvenirliğini sağlamak için meslektaş teyidi (member check) yapılmıştır. Üç araştırmacı tarafından reklamlar bağımsız bir şekilde incelenerek analiz edilmiş, ardından araştırmacılar bir araya gelerek kodları karşılaştırmış ve farklı kategorilere atfedilen kodlar üzerinde üç araştırmacının da mutabık olduğu kodlar nihai olarak alınmıştır.

\section{Verilerin analizi}

Analiz sürecinde sayısal bir değerlendirmeyi ortaya koyan "içerik analizi" yapılmış, bu analizlere ek olarak reklamlarda verilen mesajlar betimsel analize tabi tutularak incelenmiştir. Betimsel analiz sırasında elde edilen veriler, daha önceden belirlenen temalara göre özetlenip yorumlanmaktadır (Yıldırım ve Şimşek, 2013). Daha önceden araştırmanın genel amacına ulaşmak adına belirlenmiş analiz çerçevelerine göre bir sınıflama yapılarak reklamlar incelendiği için bu analiz yöntemi seçilmiştir. Araştırmacılar tarafından kaydedilen reklamlarda çocuklara atfedilen roller, çocuklar ile birebir ilişkideki yetişkinlerin rolleri, çocuklar aracılığı ile yetişkinlere verilmek istenen mesajlar, doğrudan çocuklara verilen mesajlar ve bu reklamlarda yer alan toplumsal cinsiyet unsurları; her üç araştırmacı tarafından bağımsız olarak izlenerek incelenmiştir. Daha sonra araştırmacılar bir araya gelerek ortak görüşleri doğrultusunda analizleri birleştirmişlerdir.

\section{Bulgular, Yorum ve Tartışma}

Örneklem olarak seçilen, çocukların yer aldığı reklamlara ait bilgiler Tablo 1 'de sunulmuştur. 
Tablo 1. Çocukların Yer Aldığı Reklamlara Ait Bilgiler

\begin{tabular}{|c|c|c|}
\hline Markanın adı & Program adı & f \\
\hline Audio Görüntülü Diafon & Kurtlar Vadisi & 1 \\
\hline Axa Sigorta & Eşkıya Dünyaya Hükümdar Olmaz & 1 \\
\hline Aygaz Otogaz & Kurtlar Vadisi & 1 \\
\hline Bebelac & Kırgın Çiçekler & 1 \\
\hline Becel & Karagül & 3 \\
\hline Bepanthol & Eşkıya Dünyaya Hükümdar Olmaz & 1 \\
\hline Carefoursa & Eşkıya Dünyaya Hükümdar Olmaz & 1 \\
\hline Bridgestone & O Ses Türkiye & 3 \\
\hline Carte d'Or Kat Kat Puding & Kurtlar Vadisi & 1 \\
\hline Cewe Foto Kitap & Eşkıya Dünyaya Hükümdar Olmaz & 1 \\
\hline \multirow[t]{2}{*}{ Coca-Cola } & Eşkıya Dünyaya Hükümdar Olmaz & 1 \\
\hline & Karagül & 1 \\
\hline \multirow[t]{2}{*}{ Eti Canga Dark } & Kurtlar Vadisi & 1 \\
\hline & Karagül & 1 \\
\hline Iphone 6s & Kurtlar Vadisi & 1 \\
\hline Kinder Pingui & O Ses Türkiye & 1 \\
\hline \multirow[t]{2}{*}{ Kinder Süt Dilimi } & Karagül & 2 \\
\hline & Kırgın Çiçekler & 1 \\
\hline \multirow[t]{2}{*}{ Kinder } & Karagül & 1 \\
\hline & Kırgın Çiçekler & 1 \\
\hline \multirow[t]{2}{*}{ Lipton Dökme Çay } & Kurtlar Vadisi & 1 \\
\hline & Kırgın Çiçekler & 3 \\
\hline Nesquik Geleceği Besler & Kurtlar Vadisi & 2 \\
\hline Nesquik Opti-Start & Karagül & 1 \\
\hline Nn Hayat Sigortası & Kırgın Çiçekler & 2 \\
\hline \multirow[t]{2}{*}{ Nutella } & Eşkıya Dünyaya Hükümdar Olmaz & 1 \\
\hline & O Ses Türkiye & 3 \\
\hline Oreo & Kurtlar Vadisi & 3 \\
\hline \multirow[t]{2}{*}{ Otribebe } & Eşkıya Dünyaya Hükümdar Olmaz & 1 \\
\hline & Kırgın Çiçekler & 1 \\
\hline Sek Süt & O Ses Türkiye & 4 \\
\hline \multirow[t]{2}{*}{ Signal } & Karagül & 2 \\
\hline & Kırgın Çiçekler & 1 \\
\hline
\end{tabular}




\begin{tabular}{lll}
\hline \multirow{2}{*}{ Supradyn All Day } & Eşkıya Dünyaya Hükümdar Olmaz & 1 \\
\cline { 2 - 3 } & Kurtlar Vadisi & 1 \\
\hline Tadım & Eşkıya Dünyaya Hükümdar Olmaz & 2 \\
\hline Tropicana & O Ses Türkiye & 1 \\
\hline Turkcell & Eşkıya Dünyaya Hükümdar Olmaz & 3 \\
\cline { 2 - 3 } & O Ses Türkiye & 1 \\
\cline { 2 - 3 } & Kırgın Çiçekler & 2 \\
\hline Ülker & Eşkıya Dünyaya Hükümdar Olmaz & 1 \\
\cline { 2 - 3 } & O Ses Türkiye & 3 \\
\hline Ziraat Bankası & Eşkıya Dünyaya Hükümdar Olmaz
\end{tabular}

\section{Reklamlarda Çocuklara Verilen Roller}

Bu başlık altında araştırmanın ilk alt problemine cevap aranarak reklamlarda çocukların aldığı roller incelenmiştir. İncelenen 32 reklamda çocuklar; aile üyesi, öğrenci, arkadaş, bağımsız/ ürünü kullanıcısı birey, süper kahraman rollerinde görülmektedir.

Bu sonuçlara iliş̧in frekanslar aşağıda sunulmuştur.

Tablo 2. Reklamlarda Çocuklara Verilen Rollere Illişkin Frekans Tablosu

\begin{tabular}{ll} 
Çocuklara Verilen Roller & f \\
\hline $\begin{array}{l}\text { Aile üyesi } \\
\text { (çocuk, torun, kardeş) }\end{array}$ & 26 \\
\hline Öğrenci & 6 \\
\hline Arkadaş / arkadaş grubunun üyesi & 4 \\
\hline Bağımsı / ürün kullanıcısı & 4 \\
\hline Süper kahraman & 1
\end{tabular}

Tüm reklamlarda çocuklar ailenin bir üyesi olarak karşımıza çıkmaktadır. Buna ek olarak torun (Becel, Lipton Dökme Çay, Tropicana) ve kardeş (Kinder Pingui, Kinder Süt Dilimi, Lipton Dökme Çay) rollerini üstlendiği de görülmektedir. Aile üyesi olarak rol alan çocuklar yetişkinle mutlu zaman geçirirken (Becel, Bepanthol, Carte d'Or Kat Kat Puding, Cewe Foto Kitap, Oreo, Supradyn, Tadım), bakımı yapılan veya sevilen bebek (Bebelac, Becel, Coca-Cola, Nn Hayat Sigortası, Otribebe, Ülker) olarak görülmektedir. Öğrenci rollerine bakıldığında çocuklar okulda (Aygaz otogaz, Ülker, Eti Canga Dark), önlüklü olarak sokakta/evde (Ziraat Bankası, Nesquik Opti-Start) rol almaktadır. Arkadaş rolleri incelendiğinde çocukların arkadaşlarıyla eğlenceli vakit geçiren (Kinder Süt Dilimi, Nesquik geleceği besler, Ülker) ve arkadaşını olay yerine çağıran çocuk (Tropicana) oldukları görülmektedir. Tropicana reklamında çocuk keçisiyle ilgilenirken koşarak yanına 
gelen arkadaşı dedesinin zor durumunu anlatarak çocuğu olay yerine çağırmaktadır. (..."ilyas deden bıyıklarını kesiyor, deden diyordu ya benim portakallarımdan iyisini bulursanız... Muharrem emmi bulmuș") Bağımsız roller incelendiğinde ürün kullanıcısı (Iphone 6s), özgürce dolaşan çocuk (Sek Süt), ev sahibi (Eti Muzlu Süt Dilimi), olay çözücü (Tropicana) olarak görülmektedir. Iphone 6s reklamında çocuk telefonu kullanarak araştırma yapmakta, başka bir çocuk kendi yaptığı ürünü ile oyun oynarken ürünü videoya çekmektedir. Sek Süt reklamında çocuklar özgürce dolaşarak ve toplu taşıma araçlarını kullanarak çevrelerindeki insanlara, hayvanlara yardım etmektedirler. Tropicana reklamında çocuk olay çözücü rolünü üstlenmektedir. İki yetişkin portakallarından daha iyisinin bulunamayacağına dair iddiaya girmişlerdir. Dedesi girdiği bu iddia sonucu bıyıklarını kesecektir. Çocuk olayı çözer ("....Muharrem emmim dedeme Tropicana içirmiş. Tropicana teee şehirden gelip dedemin portakallarını alır") ve dedesini zor durumdan kurtarır. Süper kahraman rolünde ise çocuk sadece bir reklamda karşımıza çıkmaktadır. Eti Muzlu Süt Dilimi reklamında çocuk ürünü arkadaşından korumak için süper kahraman olmaktadır.

\section{Reklamlarda Çocuklar ile Birebir İlişkideki Yetişkin Rolleri}

Araştırmanın ikinci alt probleminde çocuk ile ilişkili yetişkin rolleri betimlenmiştir. İncelenen 32 reklamda anne, baba, büyükanne/dede, öğretmen, komşu (anne-babanın arkadaşı), öğretmen, (çocuğun) kendisinin yetişkinliği rollerine rastlanmıştır. Bu sonuçlara ilişkin frekanslar tabloda sunulmuştur.

Tablo 3. Reklamlarda Çocuklar İle Birebir Illişkideki Yetişkin Rolleri

\begin{tabular}{ll} 
Yetişkin Rolleri & F \\
\hline Anne & 23 \\
\hline Baba & 11 \\
\hline Dede/Büyükanne & 3 \\
\hline Komşu (anne baba arkadaş) & 4 \\
\hline Öğretmen & 2 \\
\hline Kendisinin yetişkinliği & 2
\end{tabular}

Yetişkin rollerine ilişkin yapılan incelemede en fazla ebeveyn (anne/baba) rolüne rastlanmaktadır. Yetişkinlerin üstlendiği rollerde en sık karşılaşılan rolün baskın olarak "anne" rolü olduğu görülmektedir.

\section{Reklamlarda Çocuklar Aracılığı ile Yetişkinlere Verilmek Istenilen Mesajlar}

Araştırmanın alt problemlerinden bir diğeri de çocuk aracılığı ile yetişkinlere verilmek istenen mesajların incelenmesidir; araştırma kapsamında ele alınan 
reklamlarda ailelere çocuk aracılığı ile verilmek istenen mesajlar ve roller betimlenmiştir. Incelenen 32 reklam; "ebeveynlik duygusu", "çocuklara ait özelliklerin ürün ile özdeşleştirilmesi" ve "aileyi çocuğuna ambalajı gıda almaya teşvik etmesi" şeklinde gruplanmıştır. Bu sonuçlara ilişkin frekanslar aşağıda sunulmuştur.

Tablo 4. Reklamlarda Çocuklar Aracılığı ile Yetişkinlere Verilmek İstenilen Mesajların Frekans Dağılımları

\begin{tabular}{ll} 
Mesajlar & f \\
\hline Ebeveynlik duygusu & 24 \\
\hline Çocuğun özelliklerinin ürün ile özdeşleştirilmesi & 3 \\
\hline Aileyi çocuğuna ambalajlı gıda almaya teşvik & 5
\end{tabular}

Tablo 4'te görüldügü gibi çocuk aracılığı ile ailelere verilen mesajların çoğu ebeveynlik duygusuna yöneliktir. Araştırmada ebeveynlik duygusu olarak; çocuğunu koruma duygusu, mutlu etme isteği, sağlıklı ve doğru beslenmesini sağlama, yaratıcılık ve hayal gücünün desteklenmesi, eğitim/ başarı/ gelecek, çocuğu ile nitelikli vakit geçirme, iyi bir birey olması alt başıklarını kapsamaktadır. Bu alt boyutlara ilişkin frekanslar Tablo 5 'te verilmiştir.

Tablo 5. Ebeveynlik Duygusuna Yönelik Alt Boyutların Frekans Dağılımı

\begin{tabular}{ll} 
Ebeveynlik Duygusuna Yönelik Alt Boyut & f \\
\hline Çocuğunu koruma duygusu & 5 \\
\hline Mutlu etme isteği & 5 \\
\hline Sağlığı / doğru beslenme & 4 \\
\hline Başarı / eğitim / gelecek & 3 \\
\hline Yaratıclık ve hayal gücünün desteklenmesi & 2 \\
\hline Çocuğu ile nitelikli vakit geçirme & 2 \\
\hline İi bir birey olması & 1
\end{tabular}

Anne babaların çocuğu koruma duygusuna yönelik mesajların verildiği reklamlarda anne babaların çocuklara olan hassasiyeti ve koruma içgüdüsü aracılığıyla ürün kullanımı teşvik edilmektedir. Nn Hayat Sigortası'nın reklamında çocuğun doğumundan başlanarak büyüme sürecinde çocuk hayat, babası ise sigortası olarak gösterilmektedir. 
Fotoğraf 1- 2. Çocuğun sigortası rolünde baba
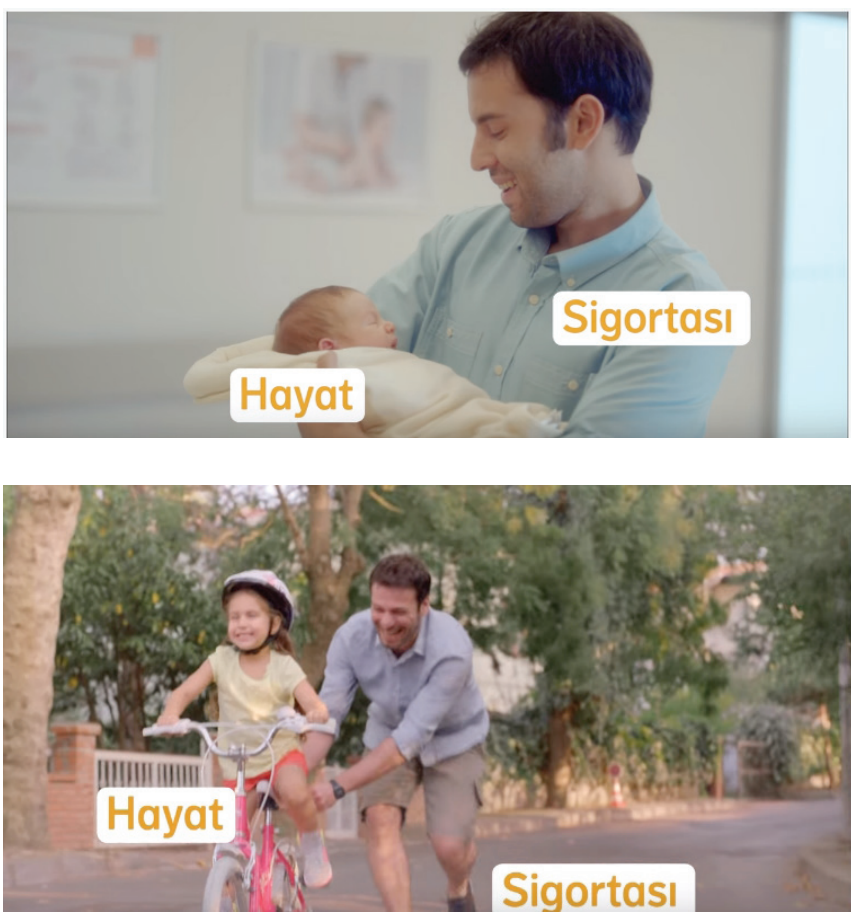

Reklam filminde, çocuk en değerli varlığımızdır, onun korunmasından anne babalar sorumludur, sorumlu anne -babanın çocuğunun hep yanında olabilmesi için sigorta yaptırması gerekir gibi mesajlar verilmektedir. "Dünyada her şeyden çok sevdiğin biri var. O senin hayatın, sen onun sigortası. İşte bu yüzden önce sen kendini Nn Hayat Sigortası güvencesine al ki onun da koruyucusu olsun... Sen yanında olmasan bile o hep güvende olsun" ifadeleri ile ailelere çocuklarının Nn Hayat Sigortası ile korunacağı, hatta aileler yanında olmasa bile güvende olacağı vurgusu yapılmaktadır. Audio Görüntülü Diyafon reklamında ise baba figürü reklamda bulunmamaktadır. Anne ve kızı evde yalnızdır ve hırsızlar eve gelmektedir. Bu reklamda anne babaların çocuklarını koruma ve güvende tutma isteği ile ürün özdeşleştirilmekte ve babaya "siz evde yokken ürün ailenizin güvenliğini sağlar, anneye de eşiniz evde yokken ürün sizin ve çocuğunuzun güvenliğini sağlar" olarak iki ayrı şekilde mesaj verilmektedir. Bridgestone reklamında özellikle trafik kazalarına vurgu yapılmaktadır. Ürünün daha erken durma gücüne sahip olduğu söylenerek, çocuğunuz ve ailenizin güvenliği için bu lastiği kullanın algısı oluşturulmaktadır. Reklamda çocuk aniden yola çıkmakta ve üzerine doğru gelen lastik ani fren yaparak çocuğa çarpmadan 2 metre önce durmaktadır. Çocuğun yanında bulunan babası lastik durduktan sonra lastik ile çocuk arasına geçerek, (görsel olarak) bu ürünü kullanarak çocuğunuz ve araba arasına girer ve çocuğunuzu korursunuz düşüncesini oluşturmaktadır. 
Fotoğraf 3. Oğluna çarpmak üzere olan lastikle oğlunun arasına giren baba

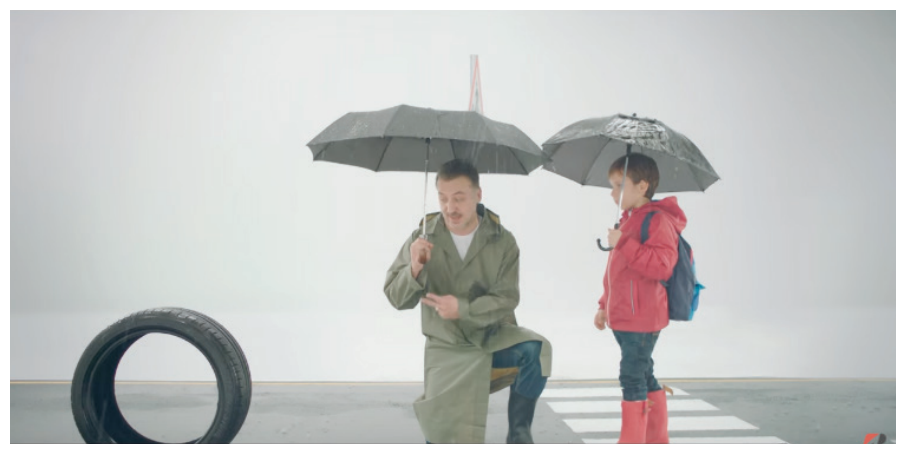

Anne babaların çocuklarını mutlu etme isteğini hedef alan reklamlarda, anne babalara bu ürünleri kullanarak çocuklarını mutlu edecekleri mesajı sözlerle ve görsellerle aktarılmaktadır. Bepanthol reklamında, çocuk annesiyle beraber bahçede görülmektedir. Soğuk hava sebebiyle yüzü kızaran çocuk mutsuz olmaktadır. Annesi tarafından yüzüne krem sürüldügünde ise çocuk annesiyle yatakta mutlu bir şekilde görüntülenmektedir.

Fotoğraf 4-5. Ürün kullanılmadan önce ve sonra annesi ile birlikte çocuk
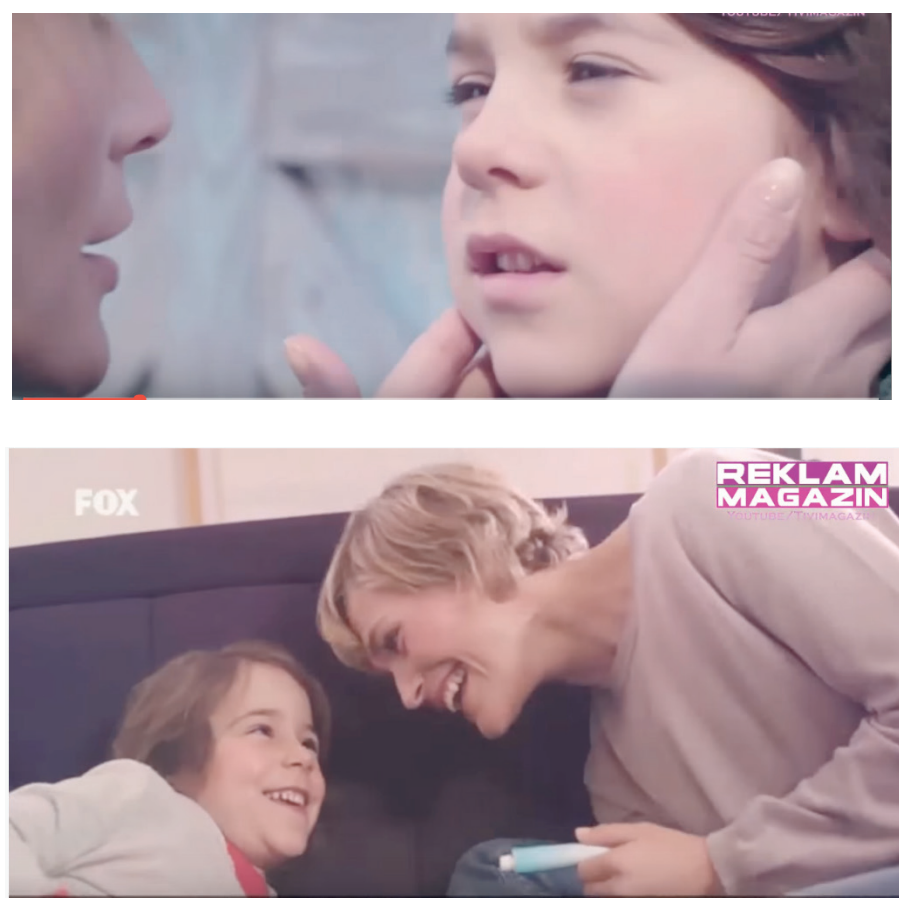
Anne babalara yönelik çocuğun sağlığı ve doğru beslenmesi ile ilgili reklamlarda, ebeveynlerin bu konudaki hassasiyetleri kullanılarak, ürünü satın almaları teşvik edilmektedir. Nesquik Opti-Start reklamında ürünün çocukların büyümesine katkıda bulunacağı mesajı şu sözler ile verilmektedir: "Çocuklarınızın mutlu ve sağlıklı büyümesine yardımcı olur". Oreo reklamında çocuk babasına bu bisküviyi nasıl yiyeceğini anlatırken, süte batırması gerektiğini söylemektedir. Reklamda çocuğa bu ürün ile süt birlikte tükettirilerek, aileye çocuklarının bu ürünle sütü severek içecekleri mesajı verilmektedir.

Çocukların eğitimleri, başarıları ve geleceklerine yönelik mesajlar içeren reklamlardan Ziraat Bankası reklamında ailelere çocuklarının geleceğinin önemsendiği "Okumayı yeni söken Leyla'nın ..... geleceği sana mı kaldı? " sözleri ile verilmektedir. Iphone $6 s$ reklamında ise çocuk telefon ile araştırma yapmakta ve kendi yaptığı kâğıttan oyuncağını videoya çekmektedir. Bu reklam ile ailelere bu ürünü çocukların araştırma ve keşfetme için kullanacakları, başarılarına ve eğitimlerine destek olacağı mesajı verilmektedir.

Anne babaların çocuklarının yaratııı ıklarını ve hayal güçlerini geliştirme isteklerine yönelik reklamlarda ise ürünün çocuklarda bu özellikleri geliştirdiği, anne babalara bu ürünleri kullanarak çocuklarının bu yönlerini destekleyecekleri mesajı sözlerle ve görsellerle verilmektedir. Nesquik (geleceği besler) reklamında "bu sadece bir bardak çikolatalı süt değil, çok daha fazlası, o dünyayı değiştirecek icatlara ve heyecan dolu maceralara başlarken hep onun yanında. Çünkü doğru bir başlangıçla çocuklar her şeyi başarabilir. Bir daha bakın. Onların geleceği değişebilir" sözleri ile ürünün çocukların keşfetme duygusunu destekleyeceği, yol göstereceği, yaratıcılıklarını artırarak farklı yeni ürünler geliştirmelerini sağlayacağı (o dünyayı değiştirecek icatlara) ve hayal güçlerini destekleyeceği (büyük hayallere başlarken hep onun yanında) bu nedenle bu ürünü çocuklarına kullandırmaları gerektiği vurgusu yapılmaktadır.

Günümüzde araştırmacı ve uzmanlar çocuklarla geçirilen zamanın süresinin değil, niteliğinin ve çocuklarla nitelikli zaman geçirilmesinin önemine vurgu yapmaktadır (Çağdaş ve Seçer, 2011; Tarhan, 2011). Ailelerin çocuklarıyla nitelikli zaman geçirmek istemeleri ve uzmanlar tarafından bu konuda yapılan açıklamaların reklamlara da yansıdığı görülmektedir. Carte d'Or Kat Kat Puding reklamında, çocuklar ve anneleri mutfakta bu ürünü hazırlarken mutlu vakit geçirmektedirler. Ürün özellikle iki parçadan oluşmakta bir parçasını anneler ocakta pişirirken, diğer parçasını çocuklar çırparak hazırlamaktadır. Ürün annelerin ve çocukların birlikte yapabilecekleri bir etkinlik olarak gösterilmektedir. Ayrıca tüm bu süreci çocuklar zevk alarak ve eğlenerek geçirir, bu şekilde ürün çocuklarınızla güzel vakit geçirmenizi sağlar mesajı verilmektedir. Supradyn All Day reklamında ise bu vitamini kullanmadığı gün anne işte, alışverişte ve evde çok yorgun ve mutsuz olarak görülmekte, ürünü kullandığı gün ise eve geldiğinde çocuklarıyla mutlu bir şekilde vakit geçirmektedir. 
Ailelerin çocuklarını iyi bir birey olarak yetiştirmek istemelerine yönelik mesajlar Sek Süt reklamında görülmektedir. Reklamda çocuklar bir bardak Sek Süt içerek evden çıkmakta, otobüste yaşlı kadına yer vermesi için genç birini koltuktan kalkması için kızdırmaktadırlar. Genç kızıp ayağa kalkınca kadın kendisine yer verdiğini sanarak teşekkür eder, genç erkek çocukların ne yapmak istediğini anlar ve gülümser. Ayrıca çocuklar yardıma intiyacı olanlara yardım etmekte, kedileri beslemektedir. Bu sütü içen çocukların iyi kalpli ve yardım sever olacağı mesajı ailelere verilmektedir. Özellikle reklamın sonunda süt şişesinden çıkan kanatlar ürüne iyilik yaptıran melek iması vermektedir.

Fotoğraf 6. Süt şişesinden çıkan kanatlar

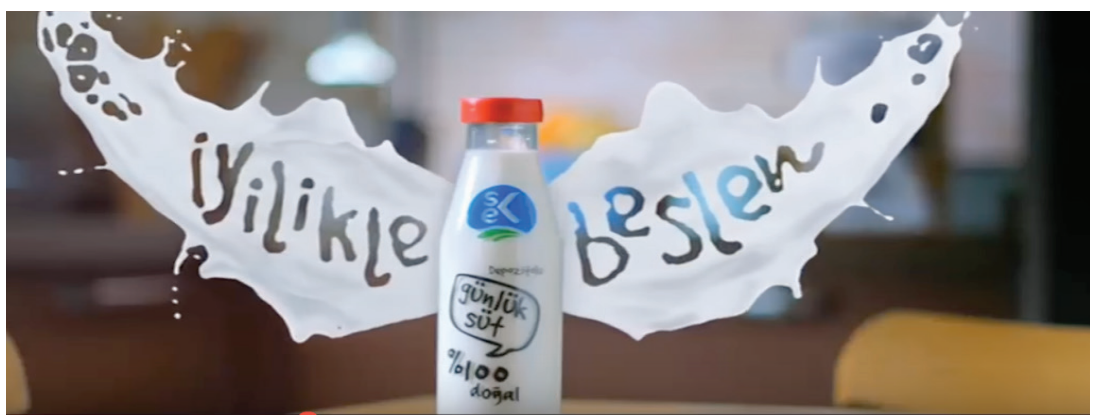

Çocuklar aracılığı ile yetişkinlere verilen mesajlardan bir diğeri ise çocukların bazı özelliklerinin ürünlerle özdeşleştirilerek yetişkinleri ürünü kullanması için teşvik etmektir. Çocukların dürüstlüğü, inandırıcılığı kullanılarak ürünün özelliği çocuğa söylettirilmektedir (" Tropicana teee şehirden gelip dedemin portakallarını alır"). Bepanthol reklamında ise çocuğun savunmasızlığı ile soğuk havalarda cildin hassas oluşu özdeşleştirilmektedir. "Soğuyan havalar cildinizin savunmasız kalmasına sebep olabilir" derken çocuğun yüzü ekranda görülmektedir. Kinder Süt Dilimi reklamında ise çocukların doğallığıyla ürünün doğal ve taze oluşu ilişkilendirilmekte ve çocuklar için en doğal atıştırmalık olduğu söylenmektedir.

Çocuklar aracılığı ile ailelere verilen mesajlardan sonuncusu ise aileleri çocuklarına ambalajı gıda alması için teşvik eden reklamlardır. Bu reklamlarda çocuklarını mutlu etmek (Bebelac "mutluluk göbüşte başlar", Nutella, Ülker, Nesquik Opti-Start) için, ödüllendirmek için, yaratıcılıklarını desteklemek için (Kinder Pingui, Nesquik geleceği besler), iyi birer yetişkin olmalarını sağlamak (Sek Süt) ya da çocuklarıyla iyi vakit geçirmek için (Carte d'Or Kat Kat Puding, Oreo) ailelerin bu ürünü çocuklarına kullandırmaları özendirilmektedirler.

Kinder "Her çocuğun gülümsemesinin ardında onu gerçekten neyin mutlu edeceğini bilen sevgi dolu bir anne vardır." Annenin çocuklarına olan sevgisi ve onları mutlu etme isteği bu ürünü çocuklarına sunması ile özdeşleştirilmiştir. 


\section{Reklamlarda Çocuklara Verilen Mesajlar}

Araştırmanın diğer alt problemi çocuklara verilen mesajların incelenmesidir. Araştırma kapsamında ele alınan reklamlarda çocuklara verilen mesajlar betimlenmiştir. Incelenen 32 reklamda olumsuz özendirme, çocukların istekleri, sorumluluk alma ve sorumluluğunu yerine getirme, olumsuz yetişkin modelleri, bilgi edinme/dokümantasyon amaçlı kullanımı içeren mesajlar şeklinde gruplanmıştır. Bu sonuçlara ilişkin frekanslar tabloda sunulmuştur.

Tablo 6. Reklamlarda Çocuklara Verilen Mesajlar

\begin{tabular}{ll} 
Çocuklara Verilen Mesajlar & F \\
\hline Olumsuz özendirme & 19 \\
\hline Çocukların isteklerini karşılamaya yönelik & 9 \\
\hline Sorumluluk alma ve sorumluluğunu yerine getirme & 1 \\
\hline Olumsuz yetişkin modelleri & 1 \\
\hline Bilgi edinme, dokümantasyon & 1
\end{tabular}

Olumsuz özendirmeyi içeren reklamlardaki mesajlar; camdan komşunun evini seyretme (Coca-Cola), yaramazlık yapmak iyidir (Eti Canga Dark), ünlü olmaya özendirme (Kinder Pingui), yetişkinlerle uygun olmayan şekilde konuşma/ davranma (Sek Süt, Tropicana), hayvanlara uygun olmayan şekilde davranma (Tropicana), okuldan çıkışın mutluluk unsuru olarak gösterilmesi (Ülker), ambalajlı gıda kullanımına teşvik etme (Eti Canga Dark, Kinder Pingui, Kinder Süt Dilimi, Kinder, Nesquik Geleceği Besler, Nesquik Opti-Start, Tadım, Tropicana, Ülker, Eti Muzlu Süt Dilimı), paylaşmamaya özendirme (Eti Muzlu Süt Dilimı), farklılıklar kötüdür (Eti Canga Dark) şeklindedir. Bu bulgulara ilişkin bazı örnekler birebir alıntılar ile birlikte aşağıda sunulmuştur.

Coca-Cola reklamında çocuklar camdan komşularının evindeki televizyonu izlerken görüntülenmektedir. Reklamda komşularının evinin pencereden çocuklar tarafından seyredilmesi olumlu ve eğlenceli bir davranış olarak gösterilmektedir. 
Fotoğraf 7. Komşunun penceresinden televizyon seyreden çocuklar

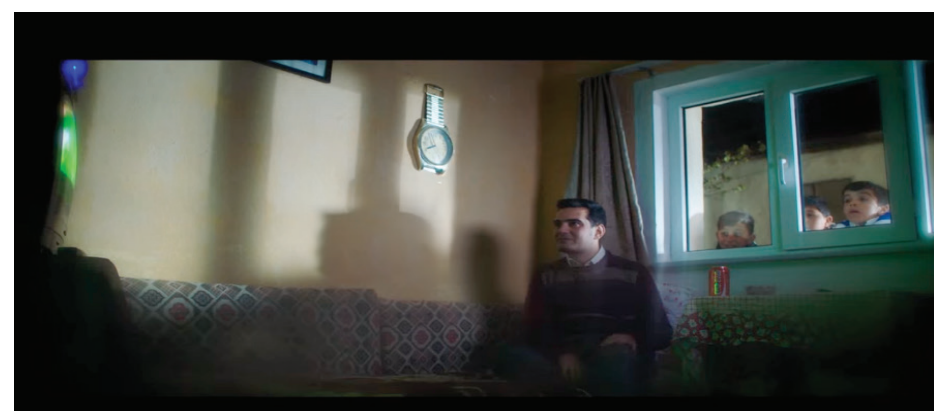

Eti Canga Dark reklamında teşvik edilen davranış yaramazlık yapmaktır. Buna ek olarak ders çalışmak sıkıcı ve asosyal bir davranış olarak yansıtılmaktadır (çocuk sınıfta en önde tek başına kitap okumaktadır, aynı anda diğer çocuklar yaramazlık yaparak hep birlikte eğlenmektedirler). Aynı reklamda "Bütün çocuklar birbirine benzer ama bazıları farklıdır, aslında onlar da yaramazlık yapmak ister" ifadesi geçmekte, daha sonra Eti Canga yiyen çocuk diğer çocuklar gibi goril olmakta ve gruba dâhil olup eğlenmektedir. Burada farklılıkların kötü olduğu, etrafındaki insanlarla aynı standartta olmanın gruba dâhil olmak için gerekli olduğu ve bu durumun mutluluk verici olduğu mesajı verilmektedir. Kinder Pingui reklamında ise çocuklar ünlü olmaya özendirilmektedir. İki kardeş de büyüyünce ünlü olmak istediğini "Anne bir fikrim var büyüyünce ünlü bir futbolcu/şarkıcı olacağım ..." şeklinde annelerine söylemekte, anneleri de çocuklarının fikirlerini "süper bir fikir" olarak nitelendirmektedir. Çocukların gelecekte büyük işler başarma hayalinin olması mutlulukla karşılanan bir durumdur. Ancak başarılı olmak her iki kardeşin de ünlü olma isteği şeklinde gösterilmektedir. Tropiacana reklamında ise çocuğun hayvanlara uygun olmayan şekilde davrandığı görülmektedir. Reklamın başkahramanı olan çocuk, reklamın başında keçinin boynuzlarına ip takmış ve onu çekmeye çalışmaktadır.

Fotoğraf 8. Keçinin boynuzlarına ip takmış ve onu çekmeye çalışan çocuk

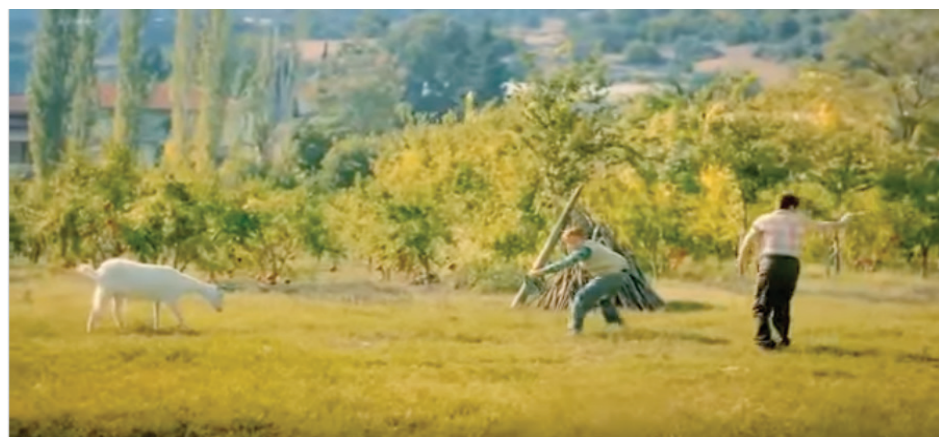


Eti Muzlu Süt Dilimi reklamında ürün arkadaşla paylaşılamayacak kadar güzel ve lezzetli olarak gösterilmektedir. Ürünün muzlusunun çıkmış olması misafir çocuğu mutlu etmiştir, bu haberi arkadaşına sevinçle vererek arkadaşına getirdiği ürünü ikram etmektedir. Fakat ev sahibi çocuk kendi evlerindeki ürünleri arkadaşından saklamakta ve onunla paylaşmak istememektedir. Ev sahibi çocuk ürünü arkadaşından korumak için süper kahraman olmaktadır. Bu noktada eğer bir şeyi çok seviyorsak onu arkadaşlarımızla paylaşmayabilir ve başkalarından koruyabiliriz mesajı çocuğa sunulmaktadır.

Tropicana ve Sek Süt reklamlarında ise yetişkinlerle uygun olmayan şekilde konuşan ve davranan çocuklar görülmektedir. Tropicana reklamında çocuğun dedesi bir konu üzerinde arkadaşı ile iddiaya girmiş ve kaybetmiştir. Olayı çözen kişi olarak çocuk dedesinin arkadaşının hile yaptığını söylemek için "Muharrem emmin antin kuntin yapmış" ifadesini kullanmaktadır. Sek Süt reklamında ise çocuklar otobüste giderken yaşlı bir kadın ayakta yolculuk etmektedir, genç bir erkek ise oturmaktadır. Çocuklar bu kişiyi kızdırarak (bıyıkları ile alay ederek) yerinden kalkmasını sağlamakta, yaşı kadın kalkan kişinin yerine oturup teşekkür ettiğinde bu kişi çocukların ne yapmak istediğini anlayıp gülümsemektedir. Ülker reklamında ise okuldan çıkış mutluluk sebebi olarak gösterilmektedir. Çocuklar sınıfta okul çıkışını saate bakarak heyecanla beklemektedir. Zilin çalması ile eğlenerek ve sevinçle dışarı çıkmaktadırlar (sınıf içinde ise oldukça sıkılmış ve mutsuz görülmektedirler).

Fotoğraf 9. Zil çalmasını bekleyen sıkılmış çocuklar

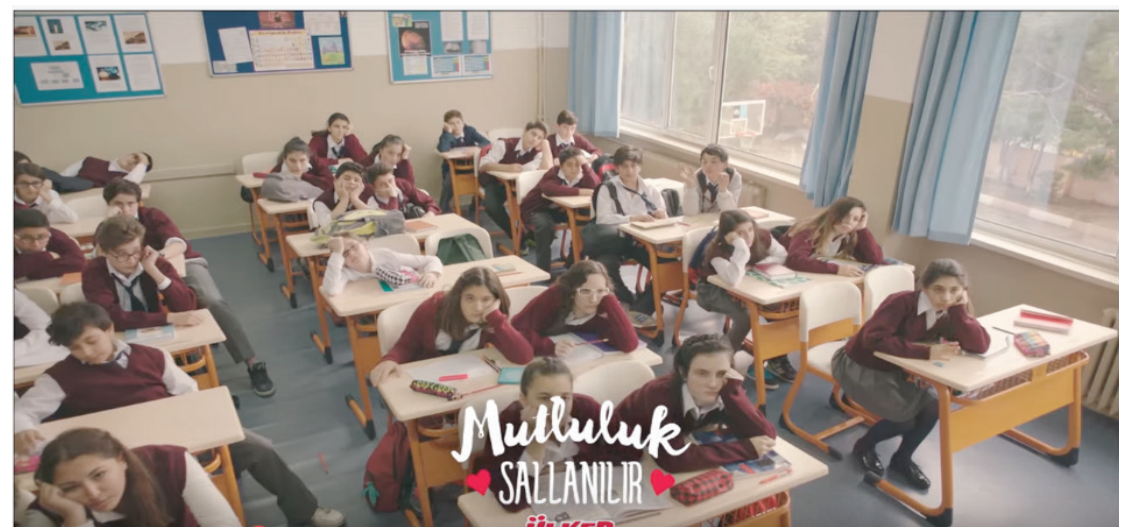


Fotoğraf 10. Zil çalmasıyla sevinçle sınıftan kaçan çocuklar

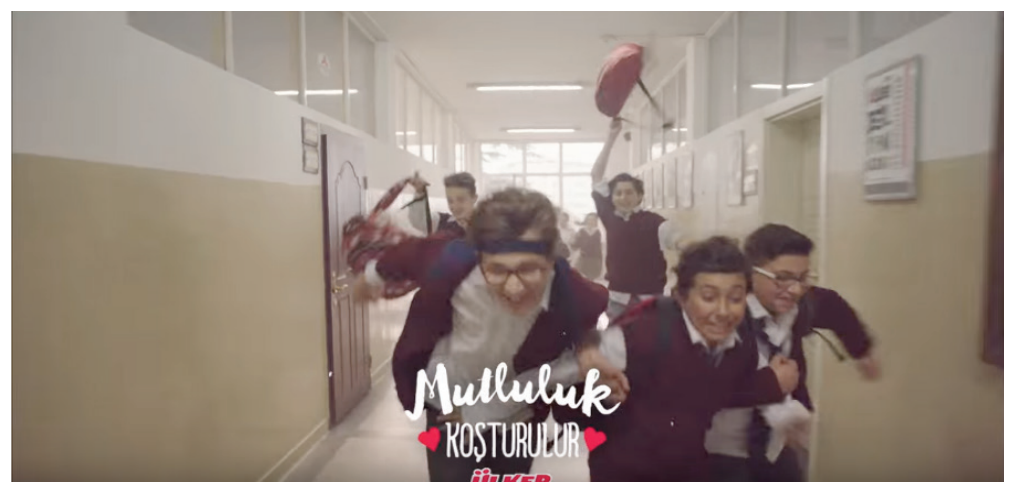

Ayrıca 10 ürünün izlenen reklamlarında çocuklar ambalajı gıda kullanımına teşvik edilmektedir: Eti Canga Dark, Kinder Pingui, Kinder Süt Dilimi, Kinder, Nesquik, Nesquik Opti Start, Oreo, Tadım, Tropicana, Ülker, Eti Muzlu Süt Dilimi. Bu reklamlarda çocuklara bu ürün sayesinde ailenizle iyi vakit geçirirsiniz (Carte d'Or Kat Kat Puding, Oreo), arkadaşlarınızla mutlu vakit geçirir ve arkadaş gruplarına kabul edilirsiniz (Tadım, Nesquik geleceği besler, Nesquik Opti-Start) gibi olumlu mesajlar verilerek çocuklar bu ambalajı ürünleri tüketmeye teşvik edilmektedirler.

Çocukların isteklerini karşılamaya yönelik hazırlanan reklamlardaki mesajlar ise; mutlu olma isteği (Kinder, Nutella), başarılı olma isteği (Carte d'Or, Kat Kat Puding), arkadaş edinme/arkadaşlarıyla mutlu vakit geçirme/ gruba dahil olma (Nesquik Geleceği Besler, Nesquik Opti-Start, Tadım), aile ile mutlu zaman geçirme (Carte d'Or Kat Kat Puding, Oreo, Supradyn) şeklindedir. Bu mesajlara ilişkin bulgular ve birebir alıntılardan bazılarına aşağıda yer verilmiştir. Carte d'Or Kat Kat Puding reklamı ile bu ürünü çocukların kendi başlarına hazırlayabilecekleri gösterilerek çocukların bireysel başarı istekleri kullanılmaktadır. Nesquik geleceği besler reklamında, çocuklar bu ürün ile hazırlanmış bir bardak süt içtikten sonra dışarı çıkarak arkadaşlarıyla mutlu vakit geçirmektedirler. Tadım reklamında ise çocukların arkadaş gruplarında kabul görme isteği ürün ile eşleştirilmekte, çocuk elinde ürün ile oyun oynayan arkadaşlarının yanına geldiğinde "Ben de oynayabilir miyim?" diye sormakta ve oyun oynayan tüm çocuklar sevinçle bu isteği kabul etmektedirler. Bu durum çocuklara arkadaş ortamına girebilmek için onlara vereceğiniz bir şey olmalı mesajı da vermektedir. Oreo reklamında çocuk babasına, ona bilmediği bir şeyi anlatacağını söylemektedir. Böylelikle çocuklara bu ürün sayesinde babaları ile hem iyi vakit geçirecekleri hem de babalarına yeni bir şeyleri öğretebilecekleri mesajı verilmektedir. 
Sadece Carte d'Or Kat Kat Puding reklamında sorumluluk alma ve sorumluluğunu yerine getirme mesajı bulunmaktadır. Reklamda ürün hazırlanırken iş bölümü yapılmaktadır ve herkesin kendi sorumluluğunu yerine getirmesi gerektiği mesajı verilmektedir.

Olumsuz yetişkin modelleri içeren bir reklam ile karşılaşıımıştır. Tropicana reklamında dedesi çocuğun saçları kızıl olduğu için çocuğa "aferin len turunçgil" demekte, ayrıca reklam süresince çocuğa yönelik "iddiayı kazandı hergele, ne oldu len" ifadelerini kullanmaktadır.

Bilgi edinme, dokümantasyon içeren Iphone $6 s$ reklamında ise araştırma yapmak amacıyla telefon kullanılmaktadır. Burada telefon kullanımı ile ilgili olumlu model olma ve özendirme bulunmaktadır. Başka bir çocuk ise kendi yaptığı ürünü videoya çekmekte ve bu çekim diğer çocuklar için öğrenme deneyimlerinin dokümantasyonu açısından model olmaktadır.

\section{Reklamlarda Yer Alan Cinsiyete Dayalı Ayrımcılık Unsurları}

Araştırmanın son alt probleminde çocukların rol aldığı reklamlarda cinsiyete dayalı ayrımcılık unsurunu incelenmiştir. İncelenen 32 reklamın 15'inde cinsiyet ayrımcılığına rastlanmıştır. Audio Görüntülü Diafon, Bebelac, Becel, Bepanthol, Bridgestone, Carte d'Or Kat Kat Puding, Kinder Pingu, Kinder Süt Dilimi, Kinder, Lipton Dökme Çay, Nesquik Geleceği Besler, Nesquik Opti-Start, Otribebe, Supradyn, Turkcell markalarının reklamları üzerinde yapılan incelemeler sonucunda, ev ve çocukların sorumluluğun annenin üzerinde, güvenliği sağlamanın sorumluluğunun da babanın üzerinde olması gibi özel roller atfedildiği görülmüştür. Bu sonuçlara ilişkin frekanslar tabloda sunulmuştur.

Tablo 7. Anne Babaya Atfedilen Özel Roller Frekans Tablosu

\begin{tabular}{lll}
$\begin{array}{l}\text { Anne/ Babaya } \\
\text { Atfedilen Roler }\end{array}$ & $\begin{array}{l}\text { Anneye ait roller } \\
\mathbf{f}\end{array}$ & $\begin{array}{l}\text { Babaya ait roller } \\
\mathbf{f}\end{array}$ \\
\hline Çocuk ve bebek bakımı & 7 & - \\
\hline $\begin{array}{l}\text { Yemek hazırlama/ } \\
\text { Genel olarak ev işleri }\end{array}$ & 3 & 1 \\
\hline Alışveriş & 1 & - \\
\hline Güvenlik & - & 3
\end{tabular}

Aşağıda cinsiyete dayalı ayrımcılığının görüldüğü bazı reklamlardan doğrudan alıntılara yer verilmiştir.

Reklamlar incelendiğinde bebek bakımı, çocuklarla ilgilenme ve alışveriş rollerinde sadece anne figürünün yer aldığı görülmektedir. Otribebe reklamında 
bebek burnunun tıkalı olması nedeniyle gece huzursuz bir şekilde uyanmaktadır. Anne yataktan kalkıp yorgun bir şekilde bebekle ilgilenirken baba ise uyumaya devam etmektedir. Bebelac reklamında "bütün anneler bilir, mutluluk göbüşte başlar" söyleminin özellikle annelere vurgu yapılarak iletilmesi, bebeğin bakımından ve mutluluğundan sorumlu kişi olarak sadece anneleri göstermektedir. Carte d'Or Kat Kat Puding reklamında üç çocuk ve her çocuğun annesi mutfakta puding hazırlamakta, üç ailede de baba figürü bulunmamakta ve çocuklarıyla ilgilenen ebeveyn olarak anneler görülmektedir. Kinder, Kinder Süt Dilimi, Kinder Pingui reklamlarında ise çocukların eğlenmesi, bakımı vs. tüm sahnelerde anne varken, babaya ilişkin hiçbir bilgi ya da görsel bulunmamaktadır. Reklamlara genel olarak bakıldığında mutfakta ve salonda çocuklarıyla ilgilenen ve etkileşime geçen sadece anne figürü kullanılmakta, baba figürü bulunmamaktadır. Baba figürünün bulunduğu sahnelerde ise babalar sofrada oturmakta ve anneler sofraya hizmet etmektedir. Becel reklamında kadın yemek servisi yaparken diğer aile üyeleri oturmaktadır. Lipton Dökme Çay reklamında tüm aile bireyleri otururken anne çay doldurmaktadır. Sadece bir reklamda (Nesquik/ Geleceği besler) anne ve baba mutfakta birlikte yemek hazırlamaktadır. Bu reklamlarda cinsiyete dayalı bir ayrımcılık göze çarpmakta, kadın figürü evde hizmet eden kişi olarak gösterilmektedir.

Bebelac reklamında "bütün anneler bilir, mutluluk göbüşte başlar" denmektedir. Audio Görüntülü Diafon, Bridgestone, Nn Hayat Sigortası reklamlarında aileyi koruyan, güvende tutan kişi baba olarak gösterilmektedir. Audio Görüntülü Diafon reklamında ürünün babanın evde olmadığı zamanda ailenin güvenliğini sağladığı dolayısıyla annenin de çocuk gibi baba figürü tarafından korunmaya gereksinimi olan bir birey olduğu gösterilmektedir. Supradyn reklamında ise "günün yorgunluğu ve yerine getirilmesi gereken sorumluluklar hayatın bir parçası" gibi kullanılan ifadeler ile birlikte çalışma ortamında ve alışveriş yaparken kadın yorgun olarak gösterilmekte ve erkek figürü reklamda hiç yer almamaktadır.

\section{Tartışma ve Sonuç}

Yapılan çalışmada incelenen reklamlarda çocuklar; aile üyesi, öğrenci, arkadaş, bağımsız/ ürünü kullanıcısı birey, süper kahraman rollerinde görülmektedir. Çocuklar aracılığı ile ailelere verilen mesajların ise ebeveynlik duygusu, çocuğun özelliklerinin ürün ile özdeşleştirilmesi ve aileyi çocuğuna ambalajlı gıda almaya teşvik etme alt boyutlarında mesajlar verilmektedir. Çocuk aracılığı ile ailelere verilen mesajların çoğu ebeveynlik duygusuna yönelik olup ebeveynlik duygusu olarak; çocuğunu koruma duygusu, mutlu etme isteği, sağlıklı ve doğru beslenmesini sağlama, yaratıcılık ve hayal gücünün desteklenmesi, eğitim/ başarı/ gelecek, çocuğu ile nitelikli vakit geçirme, iyi bir birey olması alt başlıklarını kapsamaktadır. 
Yücel ve Kara (2007) reklamlarda çocuk imgesi kullanımının işlevine ilişkin benzer olarak yaptıkları çalışmada, çocuklar sevimlilikleri nedeniyle hedef kitlenin dikkatini çekmek amacıyla, birtakım reklamlarda aktif ve bilinçli tüketiciler gibi gösterildiğinde çocuklara ve yetişkinlere ürünü kullanma önerisinde bulunulduğuna dikkat çekmişlerdir. Çalışmada ele alınan reklamlarda çocuk ürüne; yaşama sevinci, saflık, sağlık, yenilik gibi değerler yükleme amacıyla, yetişkinlere yönelik reklamlarda da sorumluluk duygusu aşılama amacıyla rol almaktadır.

Bugün artık aileler çocukları, her anlamda koruyup kollamaları gereken, koşulsuz ve sınırsız sevgilerini sunabilecekleri ailenin önemli bir parçası olarak görmektedirler (Kağıtçıbaşı, 1998). Bu çalışma kapsamında incelenen reklamların; anne babaların çocuklarını koruma duygusu ve onları mutlu etme isteği sayesinde ürünlerin pazarlanmasını kolaylaştırdığını düşündürmektedir.

Araştırma kapsamında ele alınan reklamlarda çocuklara verilen mesajlar olumsuz özendirme, çocukların istekleri, sorumluluk alma ve sorumluluğunu yerine getirme, olumsuz yetişkin modelleri, bilgi edinme/dokümantasyon amaçlı kullanımı içeren mesajlar olarak görülmektedir.

Alanyazın incelendiğinde medyada çocuklara yönelik yayımlanan programlardaki iyi ve iyi olmayan etkileşim örneklerinin, çocukların yalnızca psikolojileri üzerinde değil aynı zamanda davranışlar ve kullandıkları dil üzerinde de karakterlerin yansıtılma biçimleri doğrultusunda olumlu/olumsuz etkiler yarattığı görülmektedir (Trysinska, 2014; Glascock, 2013; Coyne ve Whitehead, 2008).

Bu çerçevede Elden ve Ulukök (2006), çocuklara yönelik reklamlarda denetim ve etikle ilgili yaptıkları bir çalışmada reklam hazırlayanların bir takım önemli görevleri olduğunu belirtmişlerdir. Çocukların daha savunmasız ve çevreden etkilenmeye açık olmaları nedeniyle reklam hazırlama ve yayınlama hizmeti veren kuruluşların çok daha dikkatli olmaları gerektiğine vurgu yapmakta ve bu süreçlerde, ileride çocuklar üzerinde ortaya çıkabilecek psikolojik sorunlar göz önüne alınarak reklam mesajlarının hazırlanması gerektiğinin altını çizmektedirler.

Araştırma kapsamında ele alınan reklamların içeriğinde sıklıkla olumsuz özendirmeye yönelik içeriklerin sunulması, henüz gelişim ve öğrenme çağında olan, doğruyu ve gerçeği ayırt etme becerisine sahip olmayan çocuklar açısından oldukça tehlike arz etmektedir. Bu tür davranışların çocuk tarafından kanıksanması gelecek dönemlerde kalıcı davranışlara dönüşebileceği için, bu tarz içeriklerin olumsuz davranışlar geliştirebileceği öngörülebilmektedir.

Yapılan çalışmada incelenen 32 reklamdan 10 tanesinde çocukların ambalajı gıda kullanımına teşvik edildiği görülmektedir. Ng ve diğerleri (2015) tarafından yapılan bir araştırmanın bulgularına göre TV izleme süreleri arttıkça, çocuklar TV'de geçen yiyecek reklamlarına çok daha fazla maruz kalmakta ve 
bu durum çocukların meşrubat, aperatif ve hazır yiyecekler gibi sağlıksız yiyecek tüketim sıklı̆ını artırmaktadır. Aynı çalışmada çocukların yaşları küçüldükçe bu tür yiyecekleri talep etme oranının arttığı da ifade edilmektedir. Benzer çalışmalar, çocukları hazır gıda, ambalajı gıda ya da meşrubat gibi yiyecek tüketimine teşvik eden ürünlerin TV reklamları aracılığıyla çocuklarda satın alma isteği uyandırdığı ve çocukların yeme alışkanlıklarında obeziteye varana kadar olumsuz yönde değişikliğe neden olduğu belirtilmektedir (Aktaş Arnas, 2006; Anwar vd., 2010; Harris, Bargh ve Brownell, 2009; Scull vd., 2014). Bunun yanı sıra Bandura'nın sosyal öğrenme teorisi doğrultusunda çocuklar popüler olarak kabul gören bu karakterleri taklit etme eğilimleri taşımaktadırlar (Bandura, 1986). Bu yiyeceklerin çekici ve etkili pazarlanmasının yanı sıra çocuklar ürünü cezbedici bulmamış olsalar dahi reklam filminde oynayan karakteri rol model aldıklarından tüketim alışkanlığı sergileyebileceklerdir. Sosyal-bilişsel kuramlara göre yiyecek ürün reklamları, herhangi bir açlık ya da reklama ilişkin farkındalık olmaksızın bu ürünlerin tüketimini artırabilmektedir (Harris, Bargh ve Brownell, 2009). Incelenen reklamların büyük çoğunluğunun çocukları sağlıksız ya da ambalajı gıdaları tüketmeye teşvik ettiği görülmektedir. Yapılan bir araştırma fast-food tarzı reklamlara maruz kalan 3-11 yaş arasındaki çocuk popülasyonunun \% 10'unun gelecekte obez olabileceğini ortaya çıkartmıştır (Chou, Rashand ve Grossman, 2005). Reklamların çocuklar üzerindeki etkisi yalnızca onları satın alma ve tüketim davranışlarına yönlendirmenin ötesinde çocukları saatlerce ekran karşısında hareketsiz tutarak fizyolojik gelişimlerinde de bozulmaya sebep olması açısından oldukça endişe verici olarak kabul edilmektedir. Sportif etkinliklere ayrılan zamanın azalması, saatlerce hareketsiz kalma, sağlıksız beslenme alışkanlıkları gibi fiziksel etkiler; kas, sinir ve iskelet sistemlerinde, söz konusu nedenlere dayalı bir takım gelişim bozukluklarına neden olabilmektedir (Arslan, 2004). Tüm bunlar göz önüne alındığında yeme alışkanlığının çocukların gelecek yaşamlarındaki sağlık durumlarının önemli bir belirleyicisi olması, bu konuda çok daha hassas davranılması gerektiği görüşünü desteklemektedir.

\section{Birleșmiş Milletler Çocuk Haklarına Dair Sözleşme'nin 24'üncü} maddesinde çocukları olabilecek en iyi sağlık düzeyine kavuşturma, besleyici yiyecekleri sağlama ve yetersiz beslenmeye karşı koruyucu önlemlerin alınması sorumluluğunun taraf devletlere verildiği ifade edilmektedir. Buna ek olarak, taraf devletler çocukların sağlığı için zararlı geleneksel uygulamaların kaldırıması ve koruyucu sağıık bakımlarının da çocuklara sağlanması hususunda her türlü önlemi alma sorumluluğundadırlar. Aynı madde kapsamında bütün toplum kesimlerinin özellikle ebeveynler ve çocukların, çocuk sağlığı ve beslenmesi, anne sütü ile beslenmenin yararları, toplum ve çevre sağlığı konusunda temel bilgileri elde etmeleri ve bu bilgileri kullanmalarına yardımcı olunması noktasında anlaşmaya taraf olan Türkiye'nin de yükümlülükleri bulunmaktadır (Çocuk Haklarına Dair Sözleşme, 1994). Bu bilgi ışığında, ülkemizde medya aracılığıyla çocuklara sunulan ambalajlı ya da sağlığa zarar verici gıdaları özendiren reklamların yayınlanmasında çok daha dikkatli olunması ve gerekli özenin gösterilmesi gerekmektedir. 
Incelenen 32 reklamın 15'inde cinsiyete dayalı ayrımcılığa rastlanmıştır. Reklamlarda kadın figürü çocuk ve bebek bakan, ev işleri ve alışveriş yapan, genel olarak evde hizmet eden kişi olarak görülmüştür. Sadece bir reklamda anne ve baba mutfakta birlikte yemek hazırlamaktadır. Bu reklamlarda, kadın figürü evde hizmet eden kişi olarak gösterilmektedir.

Anne baba olmak en genel ve ideal tanımıyla bir çocuğun yaşayabilmesi ve gelişebilmesi için gerekli olan bakım, ihtiyaç ve desteği çocuğa sağlamaktır. Türk aile yapısı incelendiğinde anne ve babalara atfedilen roller değişkenlik göstermektedir. Anne daima çocuğun bakımıyla ilgilenen, çocuğun her türlü intiyaçlarına kendini adayan ve çocukları mutlu etmeye çalışan koşulsuz bir sevgi kaynağı iken baba; aileyi geçindiren, koruyan, ailede otoriteyi sağlayan, ev işleriyle çok ilişkisi olmayan bir roldedir (Ozensel, 2004).

Gündüz Kalan (2010)'ın Kinder'in Türkiye'de yayınlanan üç reklam filmini inceleyen çalışmasında, reklamlardaki kız/oğlan çocukların ve annenin konumlandırılışının toplumsal cinsiyet rolleri ile örtüştüğünü ifade etmiştir. Gündüz Kalan'a göre reklamlarda geçen kalıp yargılar, çocuklara toplumsal cinsiyet rollerinin kazandırıması adına model olmaktadır.

Günümüzde geçerliliğini koruyan birçok kişilik kuramı, çocuğun kişilik gelişiminin şekillenmesinde anne baba tutumlarının önemli bir rol oynadığını vurgulamaktadır (Cüceloğlu, 1990). İdeal bir toplumda, kadın ve erkeklerin her anlamda (sosyal, toplumsal, hukuksal, vs.) eşit olabilmeleri ve erkeklerin de aile yapısında kadınlar kadar sorumluluk alabilmeleri gerekmektedir.

Anneyi daima mutfakta babanın ise evin maddi kaynağı olarak gösterildiği bu aile ortamında çocuklar da cinsiyetlere atfedilen bu rolleri özümseyecek ve yetişkin bireyler olduklarında bu kalıplara uygun davranışlarda bulunacaklardır. Ancak günümüzde anne baba rollerine ilişkin bakış açıları bir takım değişikliğe uğramış ve çocuğun bakımından sorumlu kişinin yalnızca anne olmadığı, bu noktada anne ve babanın eşit düzeyde sorumluluk alması gerektiği görüşü yaygın olarak kabul görmüştür (Zilanawala, 2016; Bianchi vd., 2000). Reklamlarda anne figürünün sıklıkla mutfakta ya da çocuğun temel bakım intiyaçlarıyla ilgilenen kişi olarak yansıtılması kültürel olarak aktarılmış anne baba rollerine ait cinsiyete dayalı ayrımcılığın bir yansıması olarak değerlendirilebilmektedir. Eğitim ve iş olanaklarının artmasıyla kadının işgücüne daha çok katılması, aile kavramına bakışı ve dolayısıyla ebeveynlik rollerini de değiştirmiştir. Babalar şimdi eskisinden daha çok çocuk bakımına ve ev işlerinin yapılmasına katıır hale gelmiştir.

Buna ek olarak bir güvenlik ürünü reklamında babanın yokluğunda aileyi bu ürünün koruma işlevi göreceği vurgulanmaktadır. Bu reklamın altında yatan mesaj, bir ailenin korunmasından öncelikli olarak babanın sorumlu olduğudur. Gerçek hayatta ele aldığımızda bu ürün belli bir meblağ karşıığında kadınlar tarafından da rahatlıkla satın alınabilecek bir üründür. Ancak reklamda ürün pazarı olarak 
doğrudan erkeklere hitap edilmiş ve böylelikle kadını koruma görevi de erkeğe atfedilerek, erkek kadından üstün tutulmuştur. Geçmiş zamanlarda basmakalıp haline gelen bu düşünce yapısının yansıması günümüzde de bazı reklamlarda kolaylıkla görülebilmektedir.

Bu araştırmaya benzer olarak Yücel ve Kara'nın (2007) reklamlarda geçen çocuk imgelerini araştırdıkları bir çalışmada elde ettikleri bulgular göstermektedir $\mathrm{ki}$; toplumsal cinsiyet anlayışı çocuklara yönelik reklamlarda da varlığını göstermektedir. Erkek çocuklar işe giden, kahvaltıda gazete okuyan, ailenin geçimini sağlayan, otomobillerle ilgilenen; kız çocuklar ise spor salonunda aerobik yapan, ev kadını olarak kocasının sağlığıyla ilgilenen, anneleriyle birlikte ev işleri yapan rollerde karşımıza çıkmaktadır.

Demiray ve Dündar'ın (2016) reklamları; ürün türü, markası, hedef kitlesi, dış sesin cinsiyeti, reklamda yer alan kişilerin cinsiyeti, giysisi, yaşı, bulundukları mekân ve mesaj temel kriterleri bağlamında inceledikleri çalışmalarında benzer olarak toplumsallaşma süreci içerisinde toplumsal cinsiyet rol modellerinin genellikle kitle iletişim araçlarında açık ya da örtülü biçimde, var olan ataerkil ideolojinin gereklerine uygun olarak kodlandığını belirtmektedirler. Araştırma sonucunda reklamlarda toplumsal cinsiyet açısından çocuklara sunulan kadın kimliklerinin; geleneksel rollere uygun, uysal, sevecen, güzel, bakımlı, şık, modaya uygun, güzel elbiseler giyen ve bundan mutlu olan kadın kimliği, sevgi dolu, çocuğu ile yakından ilgilenen, çocuğunun sağlığını düşünen, buna uygun tercihler yaparak mutlu olan anne kimliği, bunların yanında, ev kadını, geleneksel rollere uygun meslekler ve evde gereken işleri yapan kadın kimliği şeklinde resmedildiği belirlenmiştir. Reklamlarda çocuklara sunulan erkek kimliklerinin ise, geleneksel rollere uygun güçlü, başarılı, yenilmez, mücadeleci, macera ve gücü seven, hükmeden, sağlıklı erkek modelinde olduğu belirlenmiştir. Inceledikleri reklamlarda anneler kız çocuklarıyla, babalar erkek çocuklarıyla yer almaktadırlar. Erkek kimlikleri ise, geleneksel rollere uygun güçlü, başarılı, yenilmez, mücadeleci, macera ve gücü seven, hükmeden, sağlıklı erkek kimliğidir.

Reklamlar toplumsal cinsiyet açısından var olan yapıyı yansıtmakta, çocukların izlediği kanallarda da tekrar tekrar yayınlanarak, var olan toplumsal cinsiyet rolleri pekiştirilmektedir. Çocuklara reklamlar aracılığıyla cinsiyetlerine uygun rol modeller oluşturulmaktadır.

Eşitlik anlamında ortaya konan hukuksal düzenlemeler elbette uygarlık sürecine oldukça katkı sağlamaktadır. Ancak bu yasal düzenlemelerin yanı sıra toplumsal anlayış ve davranış biçimlerini gözden geçirme, sorgulama ve değiştirmenin, yani bir zihniyet değişikliğinin gerekliliği de öne çıkmaktadır. Bu köklü değişimi sağlayabilecek en önemli paydaş ise "medya" dır (Gönül, 2012). Bu sebeple anne baba ya da çocuk rollerinin medyada nasıl yansıtıldığı oldukça önem arz etmektedir. Kadın erkek cinsiyet ayrımcılığını pekiştiren medya unsurlarının 
yayın akışında yer alamamasına yönelik daha titiz çalışmaların yürütülmesi, zihniyet değişikliğinin sağlanmasına yardımcı olabileceği görülmektedir.

Sonuç olarak araştırma kapsamında reklamların verdikleri mesajlar ve mesaj verilirken bireylere atfedilen rollere odaklanıldığında çocuklar, incelenen reklamların hepsinde aile üyesi olarak çocuk, torun ya da kardeş rollerinde yer almaktadırlar. Yetişkinlerin, bulundukları reklamların birçoğunda ise anne karakteri ve hemen hemen yarısı kadar reklamda ise baba karakteri olarak yer aldıkları görülmektedir. Ailelerin reklamlarda yer alan ürünleri çocukları için almalarını teşvik eden reklamlar, çoğunlukla ailelerin ebeveynlik duygularına yönelik hazırlanmaktadır. Doğrudan çocuklara mesaj vererek ürüne yönlendirmeye çalışan reklamlarda ise çocuklar olumsuz davranışlara yönlendirilmekte ve yaklaşık yarısı kadar reklamda ise ailelerin çocukların isteklerini reklamlardaki ürünlerle karşılayabileceği düşündürülerek çocukları ürün tüketicileri haline getirmeyi amaçlamaktadır.

\section{Öneriler}

Elde edilen bulgular ışığında medya yapımcılarının göz önünde bulundurması gereken oldukça kritik noktalar mevcuttur. Öncelikli olarak reklamlarda yansıtılan içeriklerin çocukları doğru beslenme alışkanlığına teşvik etmesi önerilebilmektedir. Hazır ambalajlı gıda, meşrubat ve yüksek kalorili besinler yerine taze meyve sebzeler ya da doğru beslenmeye ilişkin içeriklerin sunulması, gelişim çağında olan çocuklar için çok daha sağlıklıdır.

Reklamlarda bariz olarak gösterilen anne baba rollerine ilişkin ayrımcı yaklaşımdan uzak, anne babayı çocuk bakımı ve beslenmesinde eşit gören bir yayın politikasının geliştirilmesi, tarihin eski zamanlarından bu yana süregelen cinsiyet ayrımına dayalı bakış açısını yıkmaya destek olacaktır.

Toplum içinde yer alan kalıp yargıların kırılabilmesi ya da pekiştirilmemesi adına reklam filmlerinde kız ve erkek çocuklarının bu kalıp yargılardan bağımsız olarak yalnızca çocuk oldukları üzerinde durulmalı ve verilen rollerde sadece çocuk olma özellikleri taşımaları oldukça önemlidir.

Çocuklar yaşları ve öğrenme biçimleri dolayısıyla popüler olanı kolaylıkla model alma eğilimindedirler. Bu sebeple reklamlarda kullanılan karakterler ve bu karakterlerin tükettiği ürünlerin çok daha özenli ve çocuğun herhangi bir gelişim alanına zarar vermeyecek şekilde seçilmesinde çok daha hassas davranılmalıdır.

Ulusal ve bölgesel özel televizyonların, çocukların gelişim ve öğrenme süreçlerini etkileyecek doğru ve yararlı mesajlar içeren reklamların yayımlanması konusunda ısrarcı olması gerekmektedir. Çocuklara yönelik ya da içinde çocuk geçen reklamlar tasarlanırken çocuk gelişim ve öğrenmesi adına söz sahibi olan 
psikolog, pedagog ve psikiyatrların, bilim adamlarının görüşleri ve önerileri göz önünde bulundurulmalıdır.

Medya kuruluşlarının Türkiye'nin de taraf olduğu çocukların üstün yararını öncelik olarak gören ulusal- uluslararası bütün sözleşme ve yasalara uyma zorunluluğunun altının çizilmesi ve buna ilişkin yaptırımların ağırlaştıııması gerekmektedir.

Teknolojinin ve teknoloji bombardımanın bugün gelmiş olduğu noktalar göz önüne alınarak, gerek risk altındaki bireylerin gerekse tüm toplumun medya okuryazarlığı üzerine farkındalık geliştirebileceği uygulama ve eğitimlerin yeterince sağlanması gerekmektedir.

Reklam filmleri hazırlanırken, hedef kitlenin bilgi düzeyi, olgunluk derecesi ve izlediklerini yorumlayabilme kapasitesi öngörülmelidir. Reklamlara maruz kalan çocukların yaş grubu küçüldükçe seyrettiklerini anlama, yorumlama, analiz etme becerileri kısıtlı ve yetersiz olduğu gerçeği göz önünde bulundurulmalıdır.

Reklamların çocuklara dostluk, nezaket, samimiyet, adalet, cömertlik ve başkalarına saygı gibi pozitif ve faydalı sosyal davranışlar sergilemeye özendirmesi gerekmektedir.

\section{Kaynakça}

Aksaçlığlu, A. G. ve Yılmaz, B. (2007). Öğrencilerin televizyon izlemeleri ve bilgisayar kullanmalarının okuma alışkanlıkları üzerine etkisi. Türk Kütüphaneciliği, 21(1), 3-28.

Aktaş Arnas, Y. (2006). The effects of television food advertisement on children's food purchasing requests. Pediatrics International, 48(2), 138-145. doi:10.1111/ j.1442-200X.2006.02180.x

Aktaş, H., Özüpek, M. N. ve Altunbaş, H. (2011). Çocukların marka tercihleri ve medya tüketim alışkanlıkları. Selçuk Üniversitesi Iletişim Fakültesi Akademik Dergisi, 6(4), 115-125.

Anwar, A., Anwar, F., Joiya, H. U., ljaz, A., Rashid, H., Javaid, A. ve Mehmood, M. (2010). Prevalence of obesity among the school-going children of lahore and associated factors. Journal of Ayub Medical College, Abbottabad: JAMC, 22(4), 27-32.

Arslan, A. (2004). Bir Sosyolojik Olgu Olarak Televizyon. Uluslararası Insan Bilimleri Dergisi, 1 (1), 1-17

Ateşoğlu, i. ve Türkkahraman, M. (2009). Çocukların tüketici olarak sosyalleşmesi. Süleyman Demirel Üniversitesi Iktisadi ve Idari Bilimler Fakültesi Dergisi, 14(3). 
Avşar, Z. ve Özenirler, I. (2014). Avrupa Birliği ve Türkiye'de Çocuklara Yönelik Reklam Düzenlemeleri. Uşak Üniversitesi Sosyal Bilimler Dergisi,2014(19).

Babaroğlu, A. (2015). Cooperation behavior of preschool children to the influence of TV. Journal of Academic Social Science Studies, (32), 335-355.

Baudrillard, J. (2011). Çaresiz Stratejiler, İstanbul: Boğaziçi Üniversitesi Yayınevi.

Bianchi, S. M., Milkie, M. A., Sayer, L. C. ve Robinson, J. P. (2000). Is Anyone Doing the Housework? Trends in the Gender Division of Household Labor. Social Forces, 79(1), 191-228.

Burns, M.C. (1999). TV Turns kids into target market, The Post Standard.

Centerwall, B. S. (1992). Television and violence: the scale of the problem and where to go from here. Jama, 267(22), 3059-3063.

Cesur, S. ve Paker, O. (2007). Televizyon ve Çocuk: Çocukların TV Programlarına ilişkin Tercihleri. Elektronik Sosyal Bilimler Dergisi, 19(19).

Coyne, S. M. ve Whitehead, E. (2008). Indirect aggression in animated disney films. Journal of Communication, 58(2), 382-395. doi:10.1111/j.14602466.2008.00390.x

Cüceloğlu, D. (1990). Insan ve davranışı: psikolojinin temel kavramları. İstanbul: Remzi Kitabevi

Çağdaş, A. ve Seçer, Z. (2011). Anne-baba eğitimi. Ankara: Eğiten Kitap.

Chou, S., Rashand, I. ve Grossman, M. (2005). Fast-food Restaurant Advertising On Television and Its Influence On Childhood Obesity. Erişim 15 Mart 2016, http://www.nber.org/papers/w11879

Çocuk Haklarına Dair Sözleşme. (1994). Erişim 11 Mart 2016, http://www. ombudsman.gov.tr/contents/files/20512--Cocuk-Haklarina-Dair-Sozlesme.pdf

Çocuk Koruma Kanunu (2005).

Demiray, E. ve Dündar, S. (2016). Çocuk kanallarında yayınlanan reklamlar ve toplumsal cinsiyet. 1. Uluslararası Iletişim, Edebiyat, Müzik ve Sanat Çalışmalarında Güncel Yaklaşımlar Kongresi, Erişim 26 Mart 2016, http://www. iletisimedebiyatmuzikkongresi.org/bildiri/?sayfa=dergiayrinti\&no=62\&icerik=coc uk-kanallarinda-yayinlanan-reklamlar-ve-toplumsal-cinsiyet\&kategori=iletişim

Deveci, S. E., Gülbayrak, C., Demir, A. F., Karadağ, M. ve Koçdemir, E. (2007). İlköğretim öğrencilerinin cep telefonu, bilgisayar, televizyon gibi elektromanyetik alan oluşturan cihazları kullanım sıklığı. Fırat Tıp Dergisi, 12(4), 279-283.

Dural, A. B. ve Dural, Ş. (2015). Reklam İletileri Çerçevesinde Çocuk GüvenliğiÇocuk Hakları ve Medya Etiği. Elektronik Sosyal Bilimler Dergisi, 14(53), 186-197.

Engin, H. B. (2013). Çocuk ve Reklam: Çocuklar Olması Gerekenden Erken Büyüyor. Bildiriler Kitabı, 217. 
Elden, M. ve Ulukök, Ö. (2006). Çocuklara yönelik reklamlarda denetim ve etik. Küresel Illetişim Dergisi, 2, 1-23.

Gigli, S. (2004). Children, youth and media around the world: An overview of trends \& issues. 4th World Summit on Media for Children and Adolescents, Rio de Janeiro, Brazil.

Glascock, J. (2013). Prevalence and context of verbal aggression in children's television programming. Communication Studies, 64(3), 259-272. doi:10.1080/1 0510974.2012.755638

Gönül, A. S. (2012). Toplumsal cinsiyet eşitliğinde medyanın rolü konulu komisyon raporu. Kadın Erkek Fırsat Eşitliği Komisyonu Yayınları. Erişim 11 Mart 2016, https://www.tbmm.gov.tr/komisyon/kefe/docs/toplumsal_cinsiyet_esitliginde_ medyanin_rolu.pdf

Gülarslan, A. (2011). Tüketici Olarak Çocuk ve Ailenin Satın Alma Kararlarına Etkisi. Selçuk Üniversitesi Illetişim Fakültesi Akademik Dergisi, 6(4), 126-137.

Gündüz Kalan, Ö. (2010). Reklamda çocuğun toplumsal cinsiyet teorisi bağlamında konumlandırılışı: Kinder reklam filmleri üzerine bir inceleme. İstanbul Üniversitesi Illetişim Fakültesi Dergisi, 38, 75-89.

Harris, J. L., Bargh, J. A. ve Brownell, K. D. (2009). Priming effects of television food advertising on eating behavior. Health Psychology, 28(4), 404-413. doi:10.1037/a0014399

Hebden, L. A., King, L., Grunseit, A., Kelly, B. ve Chapman, K. (2011). Advertising of fast food to children on australian television: The impact of industry selfregulation. Medical Journal of Australia, 195(1), 20-24.

Inal, E., Baysal, B. ve Baysal, B. (2008). Reklam hukuku ve uygulaması.

Kağıtçıbaşı, Ç. (1989). Child rearing in Turkey and interventional research. Psychology and Developing Societies, 1(1), 37-52.

Kahraman, A. D. ve Aytaç, T. (2014). Sosyal Medya Çağında Reklamın Eğitim İşlevi Üzerine Bir Çözümleme.

Kaur, P. ve Singh, R. (2006). Children in Family Purchase Decision Making in India and The West: A Review, Academy of Marketing Science Review, 8. Erişim 11 Mart 2016, http://www.amsreview.org/article/kaur08-2006.pdf

Kurt, E. ve Altun, T. (2014). Televizyon Reklamlarının Illkokul Öğrencilerinin Beslenme Alışkanlıklarına Etkisi Üzerine Bir Inceleme. Akademik Sosyal Araştırmalar Dergisi, 2(7), 393-408

Merriam, S. B. (2013). Nitel Araştırma Desen ve Uygulama İçin Bir Rehber (Çev. S. Turan). Ankara: Nobel Yayınları. 
Ng, S. H., Kelly, B., Se, C. H., Sahathevan, S., Chinna, K., Ismail, M. N. ve Karupaiah, T. (2015). Reading the mind of children in response to food advertising: A cross-sectional study of malaysian schoolchildren's attitudes towards food and beverages advertising on television. BMC Public Health, 15(1) doi:10.1186/ s12889-015-2392-z

Oskay, H. A. (2015). Televizyon Reklamlarında Çocuk İmgesinin Göstergebilimsel Analizi1. Academic Journal of Information Technology, 6(4), doi: 10.5824/1309-1581.2015.2.005.x Erişim 11 Mart 2016, http://www.ajit-e. org/?menu=pages $\& p=$ details_of_article\&id $=153$

Ozensel, B. (2004). Türk Toplumunda Çocuğun Yetiştirilmesinde Annenin Rolü: Konya Illi Örneği. Değerler Eğitimi Dergisi, 2 (6), 77-96.

Öncül, R. (2000). Eğitim ve eğitim bilimleri sözlüğ̈̈. İstanbul: MEB Yayınları.

Önder, A. ve Dağal, A. B. (2015). 3-6 Yaş Grubu Çocukların Ailelerinin Görüşlerine Göre Çocukların Reklamlardan Etkilenme Düzeylerinin Çeşitli Değişkenlere Ilişkin Olarak Incelenmesi. International Journal of Social Science, 35, 1-12. doi: 10.9761/JASSS2783.

Prabhakaram, K. S. ve Rao, B. D. (2006). ConceptAttainment Modelin Mathematics Teaching. New Delhi: Discovery Publishing House.

Pecora, N. O. (2002). The Business of Children's Entertainment, New York: The Guilford Press .

Scully, P., Macken, A., Leddin, D., Cullen, W., Dunne, C., ve Gorman, C. O. (2014). Food and beverage advertising during children's television programming. Irish Journal of Medical Science, 1-6. doi:10.1007/s11845-014-1088-1

Tarhan, N. (2011). Aile Okulu. (14. Baskı). İstanbul: Timaş Yayınları.

Temizyürek, F. ve Ümran, A. (2014). Çizgi Filmlerdeki Subliminal Mesajların Çocuklar Üzerindeki Etkisi. Cumhuriyet International Journal of Education, 3(3).

Tokgöz, O. (1979). Televizyon reklamları ve çocuklar. Ankara Üniversitesi SBF Dergisi, 34(01).

Trysinska, M. (2014). Kind and unkind communicative behaviour of cartoon characters as a source of language competence for young children. L1 Educational Studies in Language and Literature, 13-14(1)

Uluyağcı, C. ve Yılmaz, R. A. (2007). Televizyon reklamlarında çocuğa ilişkin toplumsal cinsiyet rollerinin sunumu. Galatasaray Üniversitesi Ileti-şi-m Dergisi, 6(6).

UNICEF (2000). Çocuk Hakları Sözleşmesi'ne Bir Bakış. Hoşgörü: Barışa Açılan Kapı, Ilköğretim Okulları lçin Kaynak Kitap, 94-100. 
Yazgan, H. I., Kethüda, Ö. ve Çatı, K. (2014), Tüketici Temelli Marka Değerinin Ağızdan Ağza Pazarlamaya Etkisi, C.Ü. Iktisadi ve Idari Bilimler Dergisi, 15(1), 237-252.

Yıldırım, A. ve Şimşek, H. (2006). Sosyal bilimlerde nitel araştırma yöntemleri. Seçkin Yayıncılık.

Yılmaz, T. T. (2014). Çocuk Iş̧̧iliğinin Yeni Formları: Çocuk Oyuncular.

Yücel, H. ve Kara, B. (2007). Reklamda çocuk imgesinin işlevi: 2006-2007 Türk televizyon reklamlarında çocuk kullanımı. Galatasaray Üniversitesi lleti-ş-im Dergisi, 6, 121-140.

Zilanawala, A. (2016). Women's time poverty and family structure: Differences by parenthood and employment. Journal of Family Issues, 37(3), 369-392. doi:10.1177/0192513X14542432 